IZA DP No. 5594

Are Intra-Household Allocations Policy Neutral? Theory and Empirical Evidence

Pierre-Andre Chiappori

Murat Iyigun

Jeanne Lafortune

Yoram Weiss

March 2011 


\title{
Are Intra-Household Allocations Policy Neutral? Theory and Empirical Evidence
}

\section{Pierre-Andre Chiappori}

Columbia University

\author{
Murat lyigun \\ University of Colorado \\ and IZA
}

\author{
Jeanne Lafortune \\ University of Maryland \\ Yoram Weiss \\ Tel Aviv University \\ and IZA
}

and Pontificia Universidad Catolica de Chile

\section{Discussion Paper No. 5594 \\ March 2011}

\author{
IZA \\ P.O. Box 7240 \\ 53072 Bonn \\ Germany \\ Phone: +49-228-3894-0 \\ Fax: +49-228-3894-180 \\ E-mail: iza@iza.org
}

\begin{abstract}
Any opinions expressed here are those of the author(s) and not those of IZA. Research published in this series may include views on policy, but the institute itself takes no institutional policy positions.

The Institute for the Study of Labor (IZA) in Bonn is a local and virtual international research center and a place of communication between science, politics and business. IZA is an independent nonprofit organization supported by Deutsche Post Foundation. The center is associated with the University of Bonn and offers a stimulating research environment through its international network, workshops and conferences, data service, project support, research visits and doctoral program. IZA engages in (i) original and internationally competitive research in all fields of labor economics, (ii) development of policy concepts, and (iii) dissemination of research results and concepts to the interested public.
\end{abstract}

IZA Discussion Papers often represent preliminary work and are circulated to encourage discussion. Citation of such a paper should account for its provisional character. A revised version may be available directly from the author. 


\section{ABSTRACT \\ Are Intra-Household Allocations Policy Neutral? Theory and Empirical Evidence ${ }^{*}$}

We develop a collective household model with spousal matching in which there exists marital gains to assortative matching and marriage quality for each couple is revealed ex post. Changes in alimony laws are shown to affect existing couples and couples-to-be differently. For existing couples, legislative changes that favor (wo)men benefit them especially if the marriage match quality is low, while, for couples not yet formed, they generate offsetting intra-household transfers and lower intra-marital allocations for the spouses who are the intended beneficiary. We then estimate the effect of granting alimony rights to cohabiting couples in Canada using a triple-difference framework since each province extended these rights in different years and requiring different cohabitation length. We find that obtaining the right to petition for alimony led women to lower their labor force participation. These results, however, do not hold - and, in some cases, are reversed - for newly formed cohabiting couples.

JEL Classification: J12, J16, J24

Keywords: intra-household allocations, matching, cohabitation, alimony laws

Corresponding author:

Jeanne Lafortune

Department of Economics

University of Maryland

3105 Tydings Hall

College Park, MD 20742

USA

E-mail: Lafortune@econ.umd.edu

\footnotetext{
Carolina Gonzalez-Velosa provided very useful research assistance. Jeanne Lafortune acknowledges financial support from the SSHRC of Canada. Pierre-Andre Chiappori gratefully acknowledges financial support by the NSF Economics Award No: SES-05-32398 and Murat lyigun thanks NSF for Human and Social Dynamics Grant No: SES-0527751. All remaining errors are our own.
} 


\section{Introduction}

Since the seminal work of Becker (1973), economists have greatly progressed in their understanding of household behavior, from both a theoretical and an empirical perspective. In particular, several empirical studies have established that factors affecting spousal bargaining power or marriage-market conditions, such as targeted transfers, laws governing divorce, alimony and abortion, or marriage-market sex ratios, also affect the allocation of household resources (Duflo 2000, Angrist, 2002, Chiappori et al., 2002, Oreffice 2007, Attanasio and Lechène 2009, to cite just a few). Several of these contributions exploit particular policy changes as natural experiments in order to identify the impact of certain policies on household behavior (e.g., labor supply). Such studies, however, do not distinguish couples already married at the time of reforms from those couples that formed subsequently. Theory, however, strongly suggests that the impact of policy on outcomes is conditional on when partnerships were formed. For existing couples, policy changes would typically affect spouses' respective bargaining powers (and possibly their divorce probabilities) in a straightforward way. Switching the post-divorce allocation of household wealth from private property to equal division, for instance, would generally favor the poorer spouse. The case of couples married after the reforms is potentially more complex, however. In particular, if individuals are forward-looking, changes that affect future bargaining positions would be taken into account in the initial matching phase, resulting in a different initial allocation of household resources, matching patterns, and possibly changes in pre-marital behavior (as discussed in Lafortune, 2010). Moreover, such effects may vary both through time and by the type and degree of commitment available to couples. In other words, one would expect that individuals who are "caught" by changes would behave differently than those who are able to react to the policy before entering into a union; and the specific nature of such responses deserve both a careful theoretical analysis and an empirical investigation.

In this paper, we present some theory and empirics that highlight such marriage-market and intra-household allocation effects. To that end, we present an integrated collective household model where the matching process as well as the prospect of divorce or separation are embedded into the collective analysis.

The main ingredients of our model are as follows: There is a continuum of men and women who live for two periods. Each agent is characterized by a single attribute, income (or human capital), with continuous distributions of incomes on both sides of the marriage market, so that each agent has a close substitute. The economic gains from marriage arise from joint consumption of a public good and a non-monetary common factor that is match

specific. This match quality for each couple is revealed ex post and those with poor matches 
may divorce. Finally, we rely on a 'Becker-Coase' framework, in the sense that utility is transferable both during the union and after separation.

Using this theoretical framework, we consider a reform that increases the wives' share of incomes after divorce, such as a universal increase in the mandatory (share of) alimony payments. Such a change in post-divorce property rights cannot affect divorce probabilities in our Becker-Coase world. However, it may (and does) influence the allocation of resources within a household, both before and after divorce - even among couples who do not eventually divorce.

We show that the short- and long-term consequences of reform are different and generally opposite of one another. For partnerships already in existence at the time of the legislative change, an increase in mandatory alimony payments can only improve the wives' welfare at the husbands' expense. While the exact scope of the reform depends on assumptions regarding commitment, either some or all women will strictly gain and no woman can lose (equivalently, no man can gain). Regarding couples who marry after the reform, the logic is quite different, because the new divorce settlement is taken into account at the matching stage, resulting in a different inter-temporal allocation of resources and welfare between spouses. Specifically, a change in alimony settlement laws aimed at favoring women will typically generate offsetting intra-household transfers, eventually resulting in lower intramarital allocations for all married women, particularly at an early stage of the union. Finally, in the presence of limits to transferability in spousal utility, reforms may affect the dissolution rate, particularly for couples who were already together before the new laws were enacted. However, the impact on partnerships formed after the legislative changes should be much smaller.

In the second part of our paper, we turn to an empirical exploration of our model by exploiting the legislative changes which granted the right to petition for alimony upon separation for cohabiting couples in Canada. That these new laws were implemented at different times in different provinces with different eligibility rules enables us to convincingly estimate the causal effect of these rules. Furthermore, one can easily distinguish between couples who started their relationships before and after the legislative changes. Our empirics thus compare the causal estimates of granting alimony rights to partnerships already in existence, when the new rules were implemented, with those that potentially reflect how individuals respond to these changes before entering a union.

Empirically, we estimate the impact of granting cohabiting couples the capacity to petition for alimony upon separation. Finding the impact of such a legislation is not easy as there is an obvious endogeneity problem: regions that implement such a rule may be distinct from those that do not. Similarly, comparing couples who "register" their union with 
those who do not is not likely to lead to a causal effect, due to the obvious selection bias. Furthermore, in the case of cohabiting couples, few countries have implemented rules with variations which allow the construction of a credible "control group" for the estimation of a causal impact (see Rangel, 2006, for a notable exception).

The context studied here is particularly interesting because not only were "commonlaw spouses" - as cohabiting couples are called in Canada - granted alimony rights at different time periods in different provinces, but also each province defined differently the length of cohabitation required to qualify for such rights. This provides a very rich source of variation for our analysis in which we employ a triple-difference strategy (based on province, time and relationship duration) in order to identify the causal impact of the legal change. Furthermore, many of these legal changes were implemented not in response to a demand from cohabiting couples but as a way to offer homosexual couples - who, at that time, were unable to legally marry — the same legal protection as their heterosexual counterparts, thus diminishing the potential problem of endogenous adoption of the laws.

Using labor supply as a proxy for one's share of household resources (something that has been employed previously but mostly in the context of married couples), we directly search for evidence that alimony rights influence spousal bargaining power. Alimony rights are likely to benefit women as they are rarely granted to men. ${ }^{1}$ The results we obtained here suggest that, as cohabiting relationships were granted alimony rights, women were more likely to attend school and stop working and less likely to work full-time whereas men became more likely to work and less likely to study or have work interruptions. These results hold within a given relationship over time, but they do not apply to individuals who were married, as those already benefited from these rights and thus were unaffected by the new laws. More importantly, however, we find contrasting outcomes for the new alimony rights' impact on the behavior of cohabiting couples who entered a union after the alimony rights were granted: among such couples, the impact of the law is limited and when observed, it is women - and not men - who were less likely to study and to have fewer work interruptions, whereas they were more likely to work or work full time.

Our results also suggest that the institution of alimony rights for cohabiting couples led to longer periods of cohabitation but also that fewer of these unions eventually lead to marriage. This appears to be only economically and statistically significant for couples who were matched before the legislative changes occurred, as we see no such effects among couples who entered a cohabiting union after the new laws were introduced.

\footnotetext{
${ }^{1}$ Moreover, men are still more likely to be earning more than their companions, rendering it more likely that transfers are made from men to women even when laws operate on the basis of 'equitable distribution' principles.
} 
These results contribute to our understanding of the dynamics between cohabitation and marriage, a topic that has been mostly the focus of sociologists and demographers (see Smock, 2000, for a review). Couples who marry after cohabitation have lower marriage quality in terms of length of relationship, propensity to divorce, etc., although this does not seem to be the case in most recent years (Schoen, 1992). And the only Canadian study on the subject (White, 1987) reaches the opposite conclusion that cohabitation reduces the probability of divorce upon marriage. Also, there are studies which document that children who live in cohabiting households perform worse in most measures (see Manning, 1995, 2001). Amador and Bernal (2008) attempt to correct for the obvious endogeneity problem in these comparisons, but still find that children with cohabiting parents have worse outcomes than those with married parents in Colombia (despite the fact that both types of households have the same rights there).

An empirical application of our main 'marriage-market induced policy-neutrality' idea in an economic development context is provided by Ambrus et al. (2010). They document that mehr, a form of Islamic bride-price which functions as a prenuptial agreement in Bangladesh due to the practice of it being only payable upon divorce, influences dowries positively in the marriage markets.

To the best of our knowledge, the only paper that has explored the impact of alimony rights on cohabiting households is Rangel (2006), who also finds that such a rule decreased female labor supply. He obtains a causal estimate of granting alimony rights to cohabiting women in Brazil by using the fact that couples with children obtained such a right, but not those without. The identification assumption we use here has the advantage of relying on a much more similar control group through the use of a tripe-difference estimator. Nevertheless, our key contribution lies in our empirics' capacity to estimate the effects of changing spousal bargaining power in existing unions and comparing them with those in relationships yet to be formed. ${ }^{2}$

The rest of the paper is organized as follows: Section 2 presents our theoretical framework; Section 3 summarizes the legal setting; Section 4 covers our estimation methodology and the data, while the subsequent section presents the empirical results. Our final section then concludes.

\footnotetext{
${ }^{2}$ Our results also mirror those obtained in the case of divorce laws in the United States (Peters, 1986, Friedberg, 1998, Chiappori et al., 2002, and Wolfers, 2006).
} 


\section{The Model}

We first present a stylized model of the marriage market intended to illustrate why the impact of granting alimony rights to couples should be different for couples already in a union at the time of the legislative change than for couples who unite after the law is enacted. Our model is based on a frictionless matching framework a la Becker-Shapley-Shubik; the reader is refered to Browning et al. (in progress) for a general presentation. In the theory section, we will not distinguish between marriage and cohabitation. And, often times, we shall use the terms 'husband' and 'wife' loosely to refer to the man and the woman in a cohabitation relationship, respectively. In the empirical work that follows, however, we shall distinguish these two types of partnership based on how the law treats the alimony obligations in each case. In particular, we shall explore whether there is any empirical evidence of this kind of policy neutrality in the context of cohabiting partners in Canada. And, in our conclusion, we'll have more to say on the distinctions between marriage versus cohabitation.

Our theoretical conclusions can be summarized as follows. A change in the rules governing property rights over the distribution of family assets redistributes expected lifetime utilities between spouses in exisiting couples. Regarding couples formed after the reform, in our Beckerian framework (transferable utility both within and outside marriage), the change has no impact on individual lifetime utilities at the time of marriage. Consequently, any policy that raises the utility of women following divorce must reduce their total utility while married.

\subsection{Preferences}

The economy is made up of individuals who live for two periods. They are characterized by their income, $y$ for men and $z$ for women. In each period, they derive utility from consumption of $n$ private goods, $q^{1}, \ldots q^{n}$ and $N$ public goods $Q^{1}, \ldots, Q^{N}{ }^{3}$ Let $p^{1}, \ldots p^{n}$ and $P^{1}, \ldots, P^{N}$ denote the corresponding prices, with the normalization $p^{1}=1$. Married people also derive satisfaction from the quality of their match, $\theta$. In order to remain within the standard 'Becker-Coase' framework, which relies on transferable utilities, we assume that couples' preferences are of the generalized quasi-linear (GQL) form (see Bergstrom, 1989).

$$
u_{i}\left(q_{i}, Q\right)=A(Q) q_{i}^{1}+B_{i}^{m}\left(Q, q_{i}^{-1}\right)+\theta
$$

\footnotetext{
${ }^{3}$ The number of public and private goods need not be strictly greater than one. Our main conclusions go through intact in a more specific version of the model in which $n=N=1$.
} 
where $Q=\left(Q^{1}, \ldots, Q^{N}\right)$ is the vector of public consumption by the couple, $q_{i}=\left(q_{i}^{1}, \ldots q_{i}^{n}\right)$ is the vector of private consumption of member $i$ and $q_{i}^{-1}=\left(q_{i}^{2}, \ldots q_{i}^{n}\right)$. Here, $A$ and $B_{i}^{m}, i=$ $h, w$, are positive, increasing, concave functions such that $A(0)=1$ and $B_{i}^{m}(0)=0$, and good 1 is the 'numeraire' that can be used to transfer utility between spouses at a constant 'exchange rate'.

Similarly, when single or after divorce, preferences take the strictly quasi-linear form: ${ }^{4}$

$$
u_{i}^{s}\left(q_{i}, Q\right)=q_{i}^{1}+B_{i}^{s}\left(Q, q_{i}^{-1}\right)
$$

where, again, the $B_{i}^{s}, i=h, w$, are increasing concave functions, with $B_{i}^{s}(0)=0$. By quasilinearity, none of the optimal levels of private and public consumption (except for good 1) depend on income. Let the latter be denoted $\left(\bar{Q}, \bar{q}_{i}^{-1}\right)=\left(\bar{Q}^{1}, \ldots, \bar{Q}^{N}, \bar{q}_{i}^{2}, \ldots \bar{q}_{i}^{n}\right)$. To simplify notation, we choose units such that $B_{i}^{s}\left(\bar{Q}, \bar{q}_{i}^{-1}\right)=\sum_{j=1}^{N} P^{j} \bar{Q}^{j}+\sum_{k=2}^{n} p^{k} \bar{q}_{i}^{k}, i=h, w$. Then, the indirect utility of a single person equals his or her income.

If a man with income $y$ is matched with a woman with income $z$, they can pool their incomes. Given GQL preferences, utility is transferable between spouses. There is a unique efficient level for the consumption of each of the public goods and each of the private goods 2 to $n$, and these levels depend only on the total income of the couple. The Pareto frontier is linear and given by

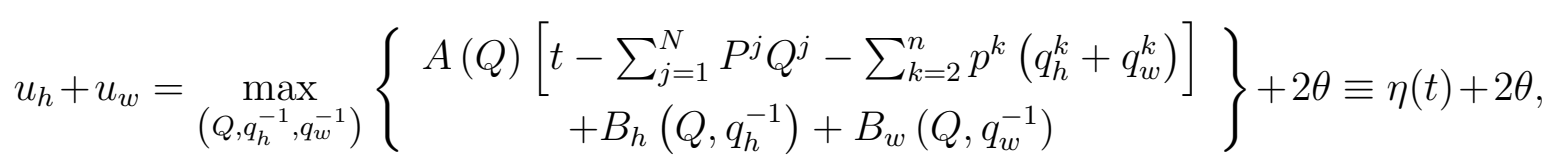

where $t \equiv y+z$ is the total family income while $u_{h}$ and $u_{w}$ are the attainable utility levels that can be implemented by the allocations of the private good $q^{1}$ between the two spouses, given the efficient consumption levels of all other goods. Assuming, as is standard, that the optimal public consumptions are such that $A(Q)$ is increasing in $Q$, we see that $\eta(t)$ is increasing and convex in $t .{ }^{5}$ It follows that the two individual traits ( $y$ and $z$ ) of a couple are complements within the household. This generates positive economic gains from marriage in the sense that the material output $\eta(t)$ the partners generate together exceeds the sum of

\footnotetext{
${ }^{4}$ Both GQL preferences when married and quasi linear utilities when single are necessary to generate the Becker-Coase benchmark in which, in a static context, divorce laws do not affect divorce probabilities; see Clark (1999) and Chiappori, Iyigun, Weiss (2007).

Since one of our primary objectives is to explore if and when alimony divorce laws affect divorce rates, we adopt these preference specifications as our stringent benchmark. See Chiappori, Iyigun and Weiss (2008) for an example of a household model which generates a strictly linear Pareto frontier after divorce.

${ }^{5}$ By the envelope theorem, the derivative $\eta^{\prime}(t)$ is equal to $A(Q)$. Therefore, $\eta$ is increasing in $t$ and, if $A(Q)$ is increasing in $t$ as well, then $\eta$ is convex. Note that a sufficient (but, by no means, necessary) condition is that public consumptions are all normal.
} 
the outputs that the partners can obtain separately. Specifically, the marital surplus $\eta(t)-t$ rises with the total income of the partners, $t$.

For any couple, match quality $\theta$ is drawn from a fixed distribution $\Phi$ with a mean $\bar{\theta} \geq 0$. Upon union, both spouses expect to derive the same non-monetary utility from marriage, $\bar{\theta}$. At the end of the first period, the match quality is revealed; a realized value of $\theta$ that is below the expected level $\bar{\theta}$ constitutes a negative surprise that may trigger legal separation. ${ }^{6}$

\subsection{Family Decisions and Commitment}

The decision variables for a couple in each period are the amounts of the public and private goods that the couple purchases and the division of the 'numeraire' private good between them. At the beginning of each period, partners agree to buy the unique efficient levels of all goods, namely the quantities which shift the linear utility Pareto frontier outward as much as possible. There are no commitment issues involved here because (by construction) the levels of consumption within a period cannot be changed and each spouse can predict that, in the second period, consumption will be chosen at the unique and efficient level. ${ }^{7}$

Concerning the division of the numeraire good, however, there is a conflict between the two partners and the question is how it is resolved. As we shall show, in our frictionless matching framework with continuous distributions of agents, competition at the time of marriage fully determines the expected lifetime utility shares of the partners. However, in the two period context discussed here, the share of the private good that each married spouse receives can vary across time. The second-period division, which is anticipated when partners choose to unite, depend on the assumption made on intrahousehold commitment. Since no agreement has been reached so far in the theoretical literature, we shall consider here the two polar cases. In the no-commitment case, the second period allocation is determined at the beginning of the second period by some known mechanism (such as Nash Bargaining); the marriage market clears based only on the flexibility in the first-period allocations, each agent rationaly anticipating the second period outcomes. In the alternative, commitment context, partners can sign binding contracts which determine allocations in both periods, with the agreed-upon, second-period allocations being relevant only in marriage; however, partners cannot commit not to divorce, and may choose to renegociate the second period allocation by mutual agreement.

\footnotetext{
${ }^{6}$ One could incorporate random income shocks into our model. In that case, such shocks could trigger divorce as well, but our qualitative conclusions would not be altered.

${ }^{7}$ One could also imagine that partners play a non-cooperative contribution game that ends up with lower utility for both spouses. But given that the efficient level of $Q$ can be easily implemented simply by buying and consuming that quantity of the public good, such an assumption is hard to justify here.
} 


\subsection{Endowments}

There exists a continuum of men and a continuum of women. The measure of men is normalized to unity and the measure of women is denoted by $r$, where $r \gtreqless 1$. Each man receives an idiosyncratic income at the beginning of each period; their incomes, denoted $y$, are distributed over the support $\left[y_{m}, y_{M}\right], 0<y_{m}<y_{M}$, according to some distribution $F$. Similarly, each woman gets an income $z$ at the beginning of each period, and the $z$ 's are distributed over the support $\left[z_{m}, z_{M}\right], 0<z_{m}<z_{M}$ according to the distribution $G$.

Following divorce, there can be income transfers (i.e., alimony payments) between the exspouses. We assume that these transfers are fully determined by law and no further voluntary transfers are made. Redistribution corresponds to a legal approach where property incomes or spousal earnings are treated as a common resource and each spouse has some claim on the income of the other. Specifically, if a man with income $y$ marries a woman with income $z$, her income following divorce is $z^{\prime}=\beta(y+z)$ and his income is $y^{\prime}=(1-\beta)(y+z)$. Thus the net income of a divorced person is generally different from what his or her income would have been had he or she not married. The special case in which all incomes are considered private, implying no redistribution via alimony payments, is represented by a $\beta$ that is couple-specific, namely $\beta \equiv \frac{z}{y+z} \cdot 8$

Income in our model can be interpreted as either labor or property income. For simplicity, we do not allow savings or human capital investments during marriage so that both property and human capital are constant. Given that we abstract from savings and the accumulation of wealth or human capital, the distinction between the post-divorce division of property and alimony payments is mostly semantic here. But one can interpret the variables $y^{\prime}$ and $z^{\prime}$ as the stream of incomes generated from the (underlying) assets of the couple which were redistributed according to the alimony laws that apply in legal separation (or divorce). Generally, incomes depend on the saving, human capital investment and labor supply of couples. Endogenizing these decisions in a matching model is complicated and we expect the matching pattern and the policy implications to be broadly unaffected. Therefore, the basic model treats these choices as predetermined. However, in the empirical section we shall explicitly address the effects of changes in the redistribution rules on education and labor supply. ${ }^{9}$

\footnotetext{
${ }^{8}$ In essence, this means that the wife is granted an alimony payment equal to $\beta y-(1-\beta) z$ upon legal separation (or, in the case of marriage, divorce). And, analogously, the husband gets $(1-\beta) z-\beta y$ following legal separation. Thus, net transfers flow from the husband to the wife if and only if $\frac{y}{z}>\frac{1-\beta}{\beta}$.

${ }^{9}$ See also Mazzocco and Yamaguchi (2007) and Stevenson (2008).
} 


\subsection{The Marriage Market}

In the first period, all men and women wish to 'marry' because the expected economic and non-monetary gains from marriage are positive. For heuristic purposes, assume that $r>1$, so that some women remain single. As usual, we solve the model backwards, starting with the legal separation (or, alternatively, the divorce) decision.

\subsubsection{Stable Matches and Lifetime Utilities}

Divorce At the end of the first period, the true value of match quality is revealed and each partner of a couple $(y, z)$ can decide whether or not to stay together, based on the realization of $\theta$. Because utility is transferable, the Becker-Coase theorem applies and divorce occurs whenever the total surplus generated outside the relationship is larger than what can be achieved within it. ${ }^{10}$ Denoting total income of the partners by $t=y+z$, divorce occurs whenever

$$
\eta(t)+2 \theta<t \Leftrightarrow \theta<\hat{\theta}(t)=-\frac{1}{2}[\eta(t)-t] .
$$

In words, a union dissolves if the sum of the outside options, here $t$, exceeds $\eta(t)+2 \theta$, implying that reservation utilities are outside the Pareto frontier if the partnership continues. On this basis, the ex-ante probability of divorce for a couple with endowments of $y$ and $z$ is

$$
\alpha(t) \equiv \Phi[\hat{\theta}(t)]
$$

Note that the threshold $\hat{\theta}(t)$ decreases with the income of the couple, $t$, and consequently the probability of divorce $\alpha(t)$ declines.

The expected marital output (i.e. sum of utilities) generated over the two periods is

$$
S(t)=\eta(t)+2 \bar{\theta}+[1-\alpha(t)]\{\eta(t)+2 E[\theta \mid \theta \geq \hat{\theta}(t)]\}+\alpha(t) t
$$

Note, first, that $S(t)>2 t$, because $\eta(t) \geq t$ and $E[\theta \mid \theta \geq \hat{\theta}(t)]>\bar{\theta} \geq 0$. Thus, all individuals prefer to get married rather than stay single. Secondly, $S(t)$ is increasing in $t$, hence in each partner's income. In particular, whenever women strictly outnumber men so that $r>1$, women belonging to the bottom part of the female income distribution remain single. Finally, individuals sort positively into unions. Indeed, since the 'marriage' surplus only depends on total income $t$, the cross partial $\partial^{2} S / \partial y \partial z$ is equal to $S^{\prime \prime}(t)$. One can readily

\footnotetext{
${ }^{10}$ See Clark (1999) and Chiappori, Iyigun and Weiss (2007) for detailed investigations of the transferability in the presence of public goods.
} 
prove that $S(t)$ is convex and therefore that the traits of the two partners are complements even after the risk of divorce is taken into account. ${ }^{11}$

Matching: Who Marries Whom? Given the results of transferable utility and the complementarity of individual incomes in generating surplus, a stable assignment must be characterized by positive assortative matching. That is, if a man with an endowment $y$ is married to a woman with an endowment $z$, then the mass of men with endowments above $y$ must exactly equal the mass of women with endowments above $z$. This implies the following spousal matching functions:

$$
y=F^{-1}[1-r(1-G(z))] \equiv \phi(z), \quad z=G^{-1}\left[1-\frac{1}{r}(1-F(y))\right] \equiv \psi(y)
$$

For $r>1$, all men are married and women with incomes below $z_{0}=G^{-1}(1-1 / r)$ remain single. Women with incomes exceeding $z_{0}$ are then assigned to men according to $\psi(y)$ which indicates positive assortative matching.

Positive assortative matching has immediate implications for the analysis of divorce. Because divorce is less likely when a couple has higher total income and individuals sort into marriage based on income, individuals with higher income are less likely to divorce. ${ }^{12}$

Stability Conditions The allocations that support a stable assignment must be such that the implied expected lifetime utilities of the partners satisfy

$$
U_{h}(y)+U_{w}(z) \geq S(t) ; \quad \forall y, z
$$

where $U_{h}(y)$ and $U_{w}(z)$ respectively represent the expected lifetime utilities of the husband and the wife over the two periods. For any stable marriage, equation (8) is satisfied as an equality, whereas for a pair that is not married, (8) would be satisfied as an inequality. In particular, we have

$$
U_{h}(y)=\max _{z}\left[S(t)-U_{w}(z)\right] \quad \text { and } \quad U_{w}(z)=\max _{y}\left[S(t)-U_{h}(y)\right]
$$

\footnotetext{
${ }^{11}$ See Chiappori, Iyigun and Weiss (2008) for the complete proof.

${ }^{12}$ Such a result is consistent with empirical findings on marriage and divorce patterns by schooling: individuals sort positively into marriage based on schooling and individuals with more schooling are less likely to divorce. See Browning, Chiappori, Weiss (in progress, Ch. 1).
} 
It is important to note that the stability conditions above constrain the total (two-period) expected utilities $U_{h}$ and $U_{w}$, but have no implication for the intertemporal distribution of utility over the two periods.

\subsubsection{Determination of Expected Lifetime Utilities}

General Characterization Equation (9) leads to an explicit characterization of the intrahousehold allocations. The envelope theorem applied to these conditions yields the differential equations :

$$
U_{h}^{\prime}(y)=S^{\prime}[y+\psi(y)] \quad \text { and } \quad U_{w}{ }^{\prime}(z)=S^{\prime}[\phi(z)+z] .
$$

To derive the expected spousal allocations over the two periods and along the assortative marital order, we integrate the expressions in (10). Hence, surplus share of a married man with income $y$ and that of a married woman with income $z$ are, respectively,

$$
U_{h}(y)=k^{h}+\int_{y_{m}}^{y} U_{h}^{\prime}(x) d x \quad \text { and } \quad U_{w}(z)=k^{w}+\int_{z_{m}}^{z} U_{w}^{\prime}(x) d x
$$

for some constants $k^{h}$ and $k^{w}$ which we determine below.

Pinning Down the Constants The constants $k^{h}$ and $k^{w}$ are pinned down by two conditions. First, for all married couples, the total output is known as expressed by equation (11). Hence,

$$
k^{h}+k^{w}=S[y+\psi(y)]-\int_{y_{m}}^{y} U_{h}^{\prime}(x) d x-\int_{z_{m}}^{\psi(y)} U_{w}^{\prime}(x) d x,
$$

where the left-hand side, by construction, does not depend on $y$. Secondly, it must be the case that 'the last married person' is just indifferent between marriage and singlehood. In the case with more women than men, $r>1$, we have

$$
U_{w}\left(z_{0}\right)=2 z_{0} \quad \Leftrightarrow \quad k^{w}=2 z_{0}-\int_{z_{m}}^{z_{0}} U_{w}^{\prime}(x) d x,
$$

with $z_{0} \equiv \Phi(1-r)$. Hence, $k^{h}=S\left[\phi\left(z_{0}\right)+z_{0}\right]-2 z, U_{w}(z)=2 z_{0}+\int_{z_{0}}^{z} U_{w}^{\prime}(x) d x$, and 


$$
U_{h}(y)=S[y+\psi(y)]-U_{w}[\psi(y)]=S[y+\psi(y)]-\left(2 z_{0}+\int_{z_{0}}^{\psi(y)} U_{w}^{\prime}(x) d x\right)
$$

It is important to stress that the stability conditions apply without any assumption on the level of commitment attainable by the spouses. The insight is that the conditions on the marriage market determine the allocation of lifetime utilities between spouses: because of competition, a wife would not agree to marry a husband who would provide less than the equilibrium utility — since many perfect substitutes exist - and likewise for the husband.

\subsection{The Intertemporal Allocations of Utility}

\subsubsection{The Commitment Issue}

We continue our analysis with a consideration of the allocation of lifetime utilities $U_{h}$ and $U_{w}$ between the two periods. At this point, commitment issues become crucial. While some degree of commitment is clearly achievable, there may be limits on the extent to which couples are able to commit - after all, couples could not and would not commit not to divorce. Two broad views emerge from the existing literature. Some contributors argue that only short-term commitment is attainable and that long-term decisions are generally open to renegotiation at a further stage. Others authors point out that a set of instruments, including prenuptial agreements, are available to sustain commitment. They, therefore, claim that divorce is the only limitation on commitment. Technically, marriage contracts should be seen as long-term efficient agreements under one constraint - namely that a person who wants to divorce can always choose to do so. ${ }^{13}$

In our framework, these two alternative views about commitment have a natural translation. In the first case ('commitment'), couples can commit to their spousal allocations in both periods conditional on the continuation of their marriage; the corresponding contingent allocations are ex-ante efficient under the sole constraint that divorce is unilateral. Therefore, the only constraint on intra-temporal allocations is that second-period utility should exceed singles' utility, at least insofar as divorce is not an efficient outcome. Finally, should an unexpected event occur between the two periods, such as a reform of the alimony-payment

\footnotetext{
${ }^{13}$ As in standard contract theory, we assume in all cases that a minimal level of commitment, whereby agents are able to at least commit to first-period allocations when they get married, is attainable. See Lundberg and Pollak (1993) for alternative assumptions. Also see Lundberg and Pollak (1993) and Mazzocco (2007) for further discussions of commitment issues within marriage.
} 
laws, this would not trigger a renegotiation of the initial agreement, unless the new individual rationality constraint is violated for one spouse. In the latter case, such a spouse would receive an additional share of household resources so that she becomes just indifferent between marriage and singlehood under the new law. ${ }^{14}$

In the alternative, polar case ('no commitment'), serious limits exist on the spouses' ability to commit. In this case, couples may be able to commit to the immediate (i.e. first period) allocation of resources; but future allocations cannot be contracted upon and will therefore be determined by a bargaining mechanism at the beginning of the second period. This feature is known ex ante by the agents and it influences the decisions regarding firstperiod allocations. Finally, if a reform occurs between the two periods, the new situation is taken into account during second-period bargaining; i.e., bargaining always take place 'in the shadow of the law'.

\subsubsection{Second-period Utilities}

For illustrative purposes, consider the case in which couples can commit to their spousal allocations in marriage ex ante; the no-commitment case can be solved in a similar way. No renegotiation can therefore take place unless divorce is credible. Moreover, if renegotiation does occur, it results in the minimal change needed for a union to continue, if that is indeed optimal.

Let $u_{h}^{2}(y)$ and $u_{w}^{2}(z)$ denote the pecuniary components of utility derived from the intramarital allocations respectively of husband with endowment $y$ and wife with endowment $z$ in the second period should they continue with their partnership. Hence, the husband's (wife's) total second-period utility is $u_{h}^{2}(y)+\theta\left(\operatorname{resp} . u_{w}^{2}(z)+\theta\right)$ if the union continues. Feasibility constraints require that $u_{h}^{2}(y)+u_{w}^{2}(z)=\eta(t)$.

Under unilateral divorce, each spouse can walk away with the share of family income determined by law, $\beta t$ for the wife and $(1-\beta) t$ for the husband, where $t=(y+z)$ is family income. Individual rationality implies that these outside options cannot exceed the utility payoffs if the marriage continues. Therefore, it must be the case that

$$
u_{h}^{2}(y)+\theta \geq(1-\beta) t \text { and } u_{w}^{2}(z)+\theta \geq \beta t
$$

which we shall hereafter refer as the individual rationality constraints $(I R)$. Note that these

\footnotetext{
${ }^{14}$ Such contracts are actually (second best) efficient under the constraint that agents cannot commit not to divorce. Similar ideas are used in different contexts, in particular risk sharing agreements under limited commitment. See Ligon et al. (2002) and Kocherlakota and Pistaferri (2008).
} 
conditions jointly imply that

$$
u_{h}^{2}(y)+u_{w}^{2}(z)+2 \theta=\eta(t)+2 \theta \geq t
$$

or equivalently that $\theta \geq \hat{\theta}(t)$, so that divorce is not the efficient outcome.

Any allocation such that (15) is satisfied can be implemented as part of a feasible marital contract: 15

Proposition 1 With commitment and unilateral divorce, there exists exactly one allocation that is not $\theta$-contingent and guarantees that all the constraints are satisfied for any realization of $\theta$.

Proof. The key remark is that the individual rationality constraints (15) must be binding when $\theta=\hat{\theta}(t)$ since, for that value, the couple is indifferent between marriage and divorce. Hence,

$$
\begin{gathered}
u_{h}^{2}(y)=(1-\beta) t-\hat{\theta}(t)=\frac{1}{2}(\eta(t)+(1-2 \beta) t), \\
u_{w}^{2}(z)=\beta t-\hat{\theta}(t)=\frac{1}{2}(\eta(t)-(1-2 \beta) t) .
\end{gathered}
$$

Note that, for any realization of $\theta$, either $\theta<\hat{\theta}(t)$ and divorce takes place or $\theta \geq \hat{\theta}(t)$ and utilities are equal to $(1-\beta) t+\theta-\hat{\theta}(t)$ and $\beta t+\theta-\hat{\theta}(t)$ for the husband and the wife respectively, so that the time-consistency constraints are fulfilled for both spouses.

Interestingly, the second-period utilities in union exactly reflect the utilities if separated, with the addition of the difference between the actual match quality $\theta$ and the threshold $\hat{\theta} \cdot{ }^{16}$ In particular, we have

\footnotetext{
${ }^{15}$ A natural question, however, is whether the material allocation $\left(u_{h}^{2}, u_{w}^{2}\right)$ can be contingent upon the realization of $\theta$. Contingent allocations raise specific problems. For instance, depending on the enforcement mechanism, they may require that the quality of the match be verifiable by a third party. Whether such verifiability is an acceptable assumption is not clear. It turns out, however, that under our assumption of common $\theta$, verifiability is not an issue because there exists (exactly) one allocation allocation that satisfies the incentive compatibility constraints for all $\theta$.

${ }^{16}$ If, instead, one entertains the case in which couples cannot make pre-marital allocative commitments, renegotiation would systematically take place at the beginning of the second period. If such couples reach a Nash-bargaining solution, with the utility of the husband and the wife in case of divorce as the relevant threat points, then the allocations will be such that they correspond exactly to the non $\theta$-contingent allocations under commitment. In other words, the unique second-period allocation that is not $\theta$-contingent and guarantees that the individual rationality constraints are satisfied for any realization of $\theta$ is also the Nash solution to a second-period bargaining.
} 
Corollary 2 Any increase of a spouse's utility in divorce is exactly reflected in that spouse's second-period utility even if divorce does not take place.

\subsubsection{First-period Utilities}

For each choice of $k$, we can now recover the first-period allocations. The expected two-period utilities equal

$$
\begin{gathered}
U_{h}(y)=u_{h}^{1}(y)+\bar{\theta}+(1-\alpha(t))\left\{u_{h}^{2}(y)+E[\theta \mid \theta \geq \hat{\theta}(t)]\right\}+\alpha(t)(1-\beta) t \\
U_{w}(z)=u_{w}^{1}(z)+\bar{\theta}+(1-\alpha(t))\left\{u_{w}^{2}(z)+E[\theta \mid \theta \geq \hat{\theta}(t)]\right\}+\alpha(t) \beta t
\end{gathered}
$$

where $\alpha(t)=\operatorname{Pr}(\theta<\hat{\theta})$ is the separation (or divorce) probability. These utilities must coincide with the equilibrium values derived above. Therefore, for $r>1$,

$$
\begin{aligned}
& u_{w}^{1}(z)=z_{0}+\int_{z_{0}}^{z} S^{\prime}[\phi(x)+x] d x-(1-\alpha(t))\left\{u_{w}^{2}(z)+E[\theta \mid \theta \geq \hat{\theta}(t)]\right\}-\alpha(t) \beta t \\
& u_{h}^{1}(y)= S[y+\psi(y)]-z_{0}-\int_{z_{0}}^{\psi(y)} S^{\prime}[\phi(x)+x] d x \\
&+(1-\alpha(t))\left\{u_{h}^{2}(y)+E[\theta \mid \theta \geq \hat{\theta}(t)]\right\}-\alpha(t)(1-\beta) t .
\end{aligned}
$$

\subsection{Reforming Alimony Laws}

Consider now a change in alimony payment laws that raises the wives' share of household income from $\beta$ to $\hat{\beta}$. This, of course, does not rule out the possibility that $\beta$ 's may be couplespecific (as it would be in a private-property regime). As long as utility is transferable, the Becker-Coase theorem applies and such a change does not affect divorce probabilities. In particular, the threshold $\hat{\theta}(t)$ only depends on the surplus generated by a union, not on its post-divorce division between (ex-) spouses; a couple splits if and only if its realized $\theta$ lies below the threshold, irrespective of the $\beta$ in place. But, under unilateral divorce laws, changes in $\beta$ typically result in a redistribution of the surplus between spouses during marriage. Whether a wife would benefit from the new property division rules would depend on her income, her marriage match quality and the level of commitment achieved between the spouses.

Concerning the impact on the division of marital gains, it is crucial to distinguish between existing couples, who are together when the change becomes effective, and future couples, 
who are not. For the former, unexpected legislative changes may trigger a renegotiation within the household and alter the original contract implemented. For the latter, the new legislation would be taken into account at the matching stage and reflected in the expected allocations entering marriage. We now consider these two cases successively.

\subsubsection{Existing Couples}

Consider a couple with endowments $y$ and $z$ for the husband and wife, respectively, whose match quality $\theta$ strictly exceeds the threshold $\hat{\theta}(t)$. Since the intra-household allocations, as determined in the marriage market, were individually rational, it must have been the case that neither spouse had an incentive to get divorced with the original $\beta$ in place.

Assume, first, that the spouses feel committed by the contract they initially chose, although they do not feel obligated to remain together. If $\theta$ is large enough, the wife's individual rationality requirements given by (15) are satisfied for both $\beta$ and $\hat{\beta}$. This occurs if $\theta \geq \hat{\beta} t-$ $u_{w}^{2}(z)$, where $u_{w}^{2}(z)$ denotes the continuation utility of the wife under the current agreement. Then, due to commitment, the change in divorce laws has no impact on intra-household allocations. If, on the contrary, $\theta$ is such that $\hat{\beta} t-u_{w}^{2}(z)>\theta \geq \beta t-u_{w}^{2}(z)$, then the initial agreement is no longer enforceable, since it would violate the wife's individual rationality. Hence, her second-period allocation must be adjusted upward to $\hat{u}_{w}^{2}(z)=\hat{\beta} t-\theta$, which requires an additional transfer equal to

$$
T=(\hat{\beta}-\beta) t-\theta-\frac{\eta(t)-t}{2} \geq 0
$$

From a comparative perspective, the probability of a renegotiation taking place depends on the distribution of $\theta$. In the benchmark case where $\theta$ is more or less uniform over a 'large enough' support, the probability is proportional to $(\hat{\beta}-\beta) t$. When both $\beta$ and $\hat{\beta}$ are identical across couples, the reform affects a larger proportion of higher-income couples. We conclude that the reform will affect intra-household allocations of some - but not all couples. For couples with a low realized match quality, the second-period marital allocation of the wife may no longer be sustainable. As a result, there will be more recontracting in favor of women among such couples. And since first-period spousal allocations would have already been sunk for all of the existing unions at the time of the legislative change, a more generous settlement rule for the wives would imply higher allocations for them in the second period and over their lifetimes.

Finally, in the absence of commitment, the conclusions are identical except for one aspect - namely, that renegotiation takes place between all spouses, because the reform directly 
impacts the respective threat points of all couples, even the wealthy and happy ones.

\subsubsection{Future Couples}

Now consider a couple who is not yet together at the time of the legal change in alimony laws. The expected lifetime allocations of such a couple, as given by equations (19) and (20), can be decomposed into three parts: first-period utility, second-period utility if the union is continued, and second-period utility in case of legal separation. Unlike existing unions, however, this effect is fully anticipated by the agents in the matching phase and reflected in equilibrium allocations. This has two consequences. First, the reform influences intra-household allocation in both periods. This is because the allocations of lifetime utility, which involves first- and second-period welfare, is decided during the matching process, taking into account the new law. A second and more subtle implication is that the impact of the reform on a future union is the same whether or not agents are able to commit to specific intra-household allocations ex ante. Indeed, we have seen in subsection 2.5.2 that the (non- $\theta$-contingent) allocation decided ex ante is the same in both contexts.

Using (17) and (18), we can compute the impact of a change in post-divorce allocations on individual utilities. Due to the change in $\beta$, the variations in individual utilities are given by:

$$
\Delta u_{h}^{1}=\Delta u_{w}^{2}=(\hat{\beta}-\beta) t, \quad \Delta u_{h}^{2}=\Delta u_{w}^{1}=-(\hat{\beta}-\beta) t .
$$

Hence, a divorce law that mandates more generous divorce settlements for women increases their utility in the second period whether or not the couple separates. However, the reform also lowers their first-period allocations by the same amount. Implicit in the above argument is what we have already established: in unions not yet formed, a legislative change has no effect on the expected lifetime allocations. But given that equilibrium spousal allocations need to be individually rational, more favorable divorce rules may lead to a more rapidly rising allocation path for the wives-to-be in order to ensure that their marital commitments are time consistent; in practice, they get more at the end, therefore less at the beginning of the union. In particular, all wives' expected intra-marital allocations conditional on remaining married are reduced and the reduction exactly offsets their gain in case of divorce.

Proposition 3 A change in the rules governing property rights over the distribution of family assets has no impact on welfare as measured by expected lifetime utilities at the time of marriage. To the extent that the policy raises the utility of women following divorce, it must reduce their total utility while married. 
These neutrality results relate to the literature on Ricardian equivalence (see Barro, 1974) in that an attempt by the government to redistribute income among agents is completely undone by a redistribution over time within family units. The neutrality of mandated divorce settlements is also similar to Lazear's (1990) result on the neutrality of mandated severance payments in the context of worker-firm relationships. In both cases, an attempt by the government to redistribute income among agents is completely undone by a redistribution over time within families or firms and does not affect the competitive outcome. ${ }^{17}$ This point is also made by Lundberg and Pollak (1993) regarding child allowances.

\section{Alimony Rights of Cohabiting Partners in Canada}

In Canada, the rights of cohabiting individuals in case of separation have changed dramatically over the last 35 years, mirroring the pattern of other nations. However, what sets the Canadian provinces apart from most European nations is that no "registration" of unions is required. Cohabitation, in itself, is the proof required by law for demonstrating one's commitment to the relationship.

Table 1 presents a summary of the legislative changes studied in this paper. These laws only granted spouses the right to petition for alimony upon separation. They did not grant rights to an equal division of assets, which is still, in most jurisdictions, granted to married individuals. ${ }^{18}$ The legislative shifts analyzed here occurred between 1978 (in the province of Ontario) and 2000 (in Newfoundland). There appears to be no general trend for provinces close to one another to have coordinated their legislation. It also does not appear that provinces that were more liberal or with a higher proportion of common-law spouses adopted these legislations earlier than others. Actually, the province with the most commonlaw relationships (Quebec) is the only province that has continued not to offer any protection to partners in that form of unions. ${ }^{19}$ Furthermore, most of the shifts were brought upon by cases in provincial and national courts. The majority of recent changes in legislation was due to cases involving homosexual couples rather than heterosexuals, who were then granted these benefits on the grounds of equality. This should reduce the potential for endogeneity

\footnotetext{
${ }^{17}$ Note, however, that our result relies on market forces rather than altruism to endogenize redistribution between spouses.

${ }^{18}$ Asset division was granted to common-law spouses in 2001 in Saskatchewan. We have excluded from our analysis the territories where, in general, spousal benefits and asset division rights were granted simultaneously.

${ }^{19}$ In July 2009, the Quebec Superior Court ruled that such a law was constitutional and allowed Quebec to continue with this policy in a case involving a famous tycoon and his cohabiting partner of many years who was seeking monthly alimony payments of CAN $\$ 56,000$ in addition to a payout of CAN $\$ 50$ million. In December 2010, the case was sent to the Supreme Court.
} 
according to changes in cohabiting couples' behavior.

What provides yet more source of variation for identification is that, as shown in Table 1, each geographical entity differed greatly on how they defined a common-law relationship. The required duration of cohabitation ranges from one year in Nova Scotia to five years in Manitoba. Also, six provinces reduced the requirement in terms of cohabitation length for couples with children.

How are these laws enforced? It appears that it is left to the petitioner to prove that the relationship lasted the required amount of time. Evidence such as common leases, bank accounts are useful in this matter. However, since 1993, this is facilitated by a change in the federal tax code. As of that date, common-law partners having lived together for more than 12 months (or less but with a child) must file their income taxes jointly. This shift affected all couples in all provinces at the same time.

One also needs to mention that, in all provinces, cohabitation agreements are legal and could be signed upon entry into cohabitation and stipulate the financial exchanges that would be accepted if separation ever occurs. These were not invalidated by the changes in the law. However, the courts have a record of refusing to enforce agreements that are judged to be "unfair". Furthermore, such cohabitation agreements are actually rarely signed by partners.

Finally, cohabitation in Canada is not uncommon and rising in popularity. According to Statistics Canada (2001), 16 percent of all couples were cohabiting. This is driven by the very large number of common-law unions in Quebec (where 30 percent of all unions are cohabitations) but the proportion of common-law relationships in the rest of Canada in 2001 (11.7) is still larger than that in the United States (8.2). Common-law relationships differ observationally from legal unions in many ways: they are shorter-lived, have lower fertility rates, involve younger, French-speaking and slightly more educated partner. For further details, see Statistics Canada (2001).

\section{Estimation Framework and Data}

The structure of the law discussed above seems to suggest the use of a Difference-inDifference-in-Differences (DDD) estimator since whether a relationship was subject to the law depended on 3 distinct components: the year in which the relationship started, the duration of the relationship and the province where the relationship was occurring. The special rules for parents also imply a 3-component variation: the year when the relationship started, when the child was born and in which province determined whether the relationship 
was under the influence of the new law. We now describe in detail the empirical strategy pursued and the data used in order to operationalize this identification strategy.

\subsection{The Estimation Equation}

We want to use the legislative framework presented above to estimate the impact of granting cohabiting partners the right to petition for alimony on an outcome $y_{i p t c_{j} j}$ for an individual $i$, in province $p$, whose relationship began in year $t$ observed in year $j$. Let $c_{j}$ be equal to 1 if the couple has had a child by year $j$. For each province, define the year in which the new law is implemented as $T_{p}$, the required duration as $D_{p}$ and an indicator for shortened duration when children are involved as $C_{p}$.

Define the variable $A_{p t d c_{j} j}$ as an indicator of whether the relationship was, in year $\mathrm{j}$, subject to the new rules regarding alimony that is:

$$
A_{p t c j}=\sum_{k=1}^{10} 1(p=k) * 1\left(j>T_{k}\right) * 1\left(1\left(j-t>D_{k}\right)+c_{j} * C_{k}\right)
$$

where 1(.) represents the indicator function. In each case, a couple is eligible if the relationship is still active at the time of the legal change and if it lasted more than the required amount of time or if it had a child by that time (since all provinces with special rules for children impose a relationship duration of at most one year, we will judge the presence of a child to be sufficient in itself).

Formally, this triple difference strategy translates into a regression equation which is given by:

$$
\begin{aligned}
& y_{i p t c_{j} j}=\alpha A_{p t c_{j} j}+\beta X_{i j}+\sum_{k=1}^{10} \delta_{k} 1(p=k) * 1\left(j>T_{k}\right)+\sum_{k=1}^{10} \lambda_{k} 1(p=k) * 1\left(j-t>D_{k}\right) \\
& +\sum_{k=1}^{10} \theta_{k} 1(p=k) * c_{j} * C_{k}+\sum_{k=1}^{10} \phi_{k} 1\left(j>T_{k}\right) * 1\left(j-t>D_{k}\right)+\sum_{k=1}^{10} \tau_{k} 1\left(j>T_{k}\right) * c_{j} * C_{k} \\
& +\sum_{k=1}^{10} \theta_{k} 1\left(j>T_{k}\right)+\sum_{k=1}^{10} \gamma_{k} 1\left(j-t>D_{k}\right)+\sum_{k=1}^{10} \rho_{k} * c_{j} * C_{k}+\mu_{j}+\nu_{i}+\varepsilon_{i p t c_{j} j}
\end{aligned}
$$

In (24), $\alpha$ represents the causal estimate of granting cohabiting couples the right to petition for alimony. To control for other individual-specific characteristics that could influence 
$y$, individual controls $X_{i j}$ for the age and the square of the age will be added. In order to allow for serial correlation, standard errors are clustered at the province level. Furthermore, in order to alleviate the problem of selective migration by which individuals may be moving to a particular province in response to the changes in the law, we shall assume that individuals were subject to the legislative changes in their province of birth. ${ }^{20}$ And while a more complete set of interactions may have been ideal, the sample size at hand for this study is too small to allow for more detailed interactions between province, year of formation and duration. ${ }^{21}$ Finally, many relationships are short-lived and the impact of alimony rights would likely impact both individuals still in a relationship and those who are not. In order to allow for this effect to be captured, we include the full length of the relationship or the first ten years after the beginning of the relationship for those that lasted shorter.

The required identifying assumption here is that there was no other contemporaneous shock affecting cohabiting couples who were living together for more than a certain period in provinces where the legislation was changed. This is robust to shocks occurring in a province at a given time or to couples with longer durations in a particular province being different than those in another one. Furthermore, as we specified above, in most of the recent legislative changes, the impetus for modifying the law was not a desire to modify the legal rights of cohabiting partners but more of a need to offer homosexual couples (who, at that time, were not allowed to marry legally) the same type of legal protection married heterosexual couples were afforded in case of separation.

Our objective is to contrast the parameter $\alpha$ when estimated for couples who were formed before the new legal framework and for those formed after. In the first case, we estimate the equation (24) restricting the sample to relationships that began before they could modify their behavior and avoid becoming subject to the new ruling (that is where $t<T_{p}-D_{p}$ for each province). In those regressions, the duration of the relationship $j-t$ is censored to the length of the relationship before the law changed so as to ignore potential endogenous responses to be included into the estimation. Furthermore, because of the way the sample is selected, all relationships that are still active when the law changes are by definition having lasted long enough to be subject to the alimony rules, which prevents the inclusion of the parameters $\delta_{k}$ in the estimation equation above.

We will estimate this equation to measure the impact of granting alimony rights to new couples by restricting the sample to new couples and those couples formed before the law

\footnotetext{
${ }^{20}$ Also, only 2 cross province migration episodes are recorded which, in some cases, prevent us from tracking where individuals lived when they were cohabiting. About 80 percent of the sample lives in the province where they were born.

${ }^{21}$ We will estimate $\alpha$ interacted by gender, and all terms will be interacted with a gender dummy, except for the year fixed effects, which was too costly in terms of degrees of freedom.
} 
while they were not eligible (if they ever became so).

Finally, we also restrict the sample only to new relationships and use a difference-indifference model using the province and the duration of the relationship as the only variables determining treatment. In this case, the identifying assumption is that there were no other province-specific shocks that affect relationships lasting more than a given number of years. Those regressions will be estimated in a similar way to (24), except most controls will not be included, and standard errors will also be clustered by province.

In some instances, we will not be looking at changes in behavior over the duration of a relationship but rather an outcome specific to the full relationship (such as whether the relationship became a marriage). In those instances, we only observe one instance in the relationship and will thus not be able to use relationship fixed effects. Equation (24) is then modified where $j-t$ is fixed to the relationship duration and $c_{j}$ to an indicator of whether the couple ever had a child and relationship fixed effects are replaced with province fixed effects. In this case as well, the same three samples are used as described previously to allow a contrast between relationships formed before and after the legal change.

\subsection{The Data}

In our empirical work, we use the General Social Survey (GSS) data of 2001, from Statistics Canada. This is a survey that was performed once, but it asked very detailed retrospective questions on one's education, labor market activities, children and past relationships. The total sample was 24,310 Canadians aged 15 and above in all provinces but not in the territories. The survey is also retrospective and thus subject to recall bias. Nevertheless, as long as this bias is not altered by the new alimony rules, it should not affect our results.

The data collected from the GSS measure all the characteristics needed to classify a union as subject to the new alimony rules or not: the age at which the relationship began (which, taken together with the year of birth, identifies the year in which the relationship began), the age at which it ended (or whether it was still active at the moment of the survey) and the province of birth. The variable $A$ is computed using this information for each relationship, as well as all the ingredients required as control variables in equation (24).

Our key outcomes of interest relate to the measures of relative welfare of each partner. As is common in this literature, we use labor supply as a proxy for the consumption of leisure and thus higher labor supply will be assumed to imply lower welfare. The GSS does not provide information regarding the number of hours or weeks worked. Instead, the 
respondents were asked to detail their full retrospective histories of work and education. ${ }^{22}$ Periods of work, hiatus and education are then matched to each relationship based on the years of each event. The survey only provides limited information on the spouses for each of the relationships detailed by the respondents. The data available include the age difference between the respondent and his/her partner as well as the marital status of the partner before the relationship. ${ }^{23}$

The data also provide a variety of outcomes to measure the impact of the legislation on relationship stability. First, one can determine whether the cohabitation eventually led to marriage (which can be seen as a substitute for cohabitation). The data also allow us to measure the overall duration of the relationship (including the years of marriage when relevant) and whether or not the relationship had ended at the time of the 2001 survey.

We do not use the full GSS sample. Immigrants and individuals born in the territories are excluded since their province of birth is outside the sample. Relationships that began before 1960 are also excluded so as to focus on relationships that are closer in timing to the legislative changes observed. This gives a sample of 7,520 common-law relationships and 11,279 marriages.

Summary statistics of the main variables of interest are presented in Table 2 for both marital and common-law relationships. In this table, every relationship is one observation and the summary statistics are computed using the person-specific weights provided by the survey. The first section documents the demographic characteristics of the respondents. Respondents in common-law relationships differ from those in legal unions in many ways: they are more likely to be French-speaking; Catholics or atheists; less likely to have attended religious services as teens; more likely to have a high school diploma but less likely to have a college degree. They are also much shorter-lived (16 versus 8 years) even after we take stock of the entire relationship (cohabitation plus eventual marriage). Partners were also more likely to have larger differences in age in cohabitation than in marriage. About 37 percent of the common-law relationships in the sample eventually led to marriages and about 45 percent of the couples were separated by 2001. Couples formed before and after the law

\footnotetext{
${ }^{22}$ All work episodes are described including the year they began, the year they ended and whether they involved mostly full-time or part-time work. All interruptions, which are defined as periods of more than 3 months where the individual was not working for a variety of reasons, including lack of work, sickness, maternity/paternity leaves, retirement, job switches, etc, are also mentioned as well as any educational experience. Maternity and paternity leaves are also compiled.

${ }^{23}$ Only for the current partner is more information gathered but there is a severe selection bias which prevents us from using these data. Also, most of the first generation of laws only applied to couples of the opposite sex. The data do not allow us to identify whether previous partners were of the opposite sex so all relationships in the dataset are treated as being heterosexual and thus subject to the law. Information on current partners, in any case, indicates that less than one percent of current cohabitation relationships are homosexual and thus the measurement error induced by this assumption appears to be minimal.
} 
change differ in some respects, most of which are driven by the fact that the latter started later and exclude all Quebecers.

Table 3 presents the summary statistics for our panel regressions where each observation is a year-relationship. The first set of statistics includes all years where the relationship is active while the second includes at least 10 years for all relationships, as justified in the previous section. In both samples, about 11-12 percent of years included one where an individual studied, about three-quarters included work and about two-thirds, full time. Around 12-13 percent included a work interruption and, while about 5 percent of years involved a maternity leave, a much smaller fraction included paternity leaves.

\section{The Impact of Granting Alimony Rights}

\subsection{Alimony Rights and Labor Supply}

Alimony payments are usually made from the higher-earning partner to the lower-earning one. Since over the period in question, men were still more likely to earn higher incomes than their spouses, we assume that legally requiring alimony payments favored females. Thus, we expect that, when a relationship becomes eligible for these rules, female partners decrease their labor supply provided that leisure is a normal good. This section explores changes in spousal labor supply using these various outcome measures as proxies for labor supply.

The results of the estimation of equation (24), using the three samples detailed above, are presented in Table 4. Panel A focuses on couples formed before a legislative change, while those for all unions except those that were immediately subject to the new laws when the changes were enacted are found in Panel B. Panel $\mathrm{C}$ shows the results of a simple difference-in-difference regression focusing only on couples formed after the legislation had been passed.

The results imply that, when a relationship is granted the right to petition for alimony, women are about 4.7 percent less likely to work full time and 2 percent more likely to be studying. They are also 5.3 percent more likely to have stopped working. Their likelihood of having taken maternity leave increases by 2.4 percent (although not statistically so) even if the probability of having a child is unchanged. ${ }^{24}$ Males, on the other hand, responded to the legislation in a statistically different manner. They appear to have reduced their likelihood of being in school and having suffered work interruptions but more likely to have worked, particularly full-time. They appear to have been less likely to take paternity leave but this

\footnotetext{
${ }^{24}$ Results on fertility are not presented but available upon request.
} 
result is very small in magnitude and not significant.

What is much more striking is the difference between Panel A and the following two panels of the table. Once one measures the impact of a relationship being subject to alimony rules on relationships formed after the legal change, the conclusions are very much different. This is true both in Panel B and C, despite the difference in the estimation strategy in these two samples. The coefficients are usually smaller in magnitude for couples formed after the legal change and of the opposite signs as the ones presented in Panel A. These results appear to suggest that relationships formed after the "rules of the game" were changed responded very differently to being subject to the alimony rules than those that were formed before such a legal change, and in a way that is perfectly consistent with the theoretical framework presented above. The bottom of the table presents a formal test of the equality of the coefficients. We can reject that the two sets of coefficients are equal for work interruptions and full timework (in both panels) and for work and maternity when compared with Panel B.

These findings are explored in more detail in the subsequent table where various robustness checks are performed. We, in particular, investigate the robustness of three outcomes: whether the individual studied in a given year; whether the individual worked full time; and whether the respondent had work interruptions. In the first column, the results are presented assuming that no exceptions are made for relationships with children and that the alimony rights are granted solely on the basis of the duration of cohabitation. The estimates are fairly consistent with those presented in Table 4 . The next column uses all years when the relationship was active and thus excludes years after a short relationship terminated. Doing so alters the results but more in significance than in magnitudes. This highlights the importance of having a comparison point for relationships that lasted longer which is impossible if we use only the active relationships in the sample. The next two columns compare the results restricting the sample to either older relationships, in column (3), or more recent ones, in column (4). Overall, the measured impact appears to be larger and more significant when focusing on recent legal changes than older ones even if some significant impacts are measured for working full-time in the older sample. The next column excludes all relationships from Quebec which shrinks the sample by almost half. The results on the probability of studying or suffering a work interruption lose their significance but the results on labor supply are much larger and more significant than previously. Column (6) repeats the exercise, but this time using married individuals as a placebo group. The coefficients in this case are much smaller in magnitude and rarely significant. When they are (as in the case of work interruptions) they are of the opposite sign for cohabitations. Thus, this suggests that the results obtained in the previous table are not driven by events contemporaneous 
to the legislative changes affecting all types of unions in a geographical location. The last column includes controls for forthcoming legislative changes. In all outcomes, the fact that an individual would become subject to alimony rights in 2 years has no significant effect on his or her contemporary labor supply. Furthermore, except in the case of work interruptions, the introduction of such an additional control does little to change the size and significance of the coefficients of interest.

Table 6 then explores who is more likely to respond to these new rules concerning alimony. The same three outcomes as in the previous table are presented and results are fairly similar for other outcomes. The odd columns present the coefficients of the main effect of the law, and the even ones, the interaction term between the legislative change and a dummy for the respondent being male. The theoretical framework suggests that an individual with a higher income would be more likely to respond to the policy change if there exists some capacity to commit to allocations. While the data do not offer information regarding the income of the respondent at the time of the relationship, we use two proxies: the education level and the age at which the relationship began. The first panel contrasts the treatment effect by the education level of the respondent. In the case of whether the respondent worked full-time in a given year, the legislative change appears to have affected more directly individuals with higher levels of education, as predicted by the model. While men with more education responded more strongly to the legislation in terms of work interruptions and studies (although not significantly so), it is women with lower levels of education who did so for work interruptions and women with a high school degree who did so for studying. It does appear that couples formed before age 21 responded less in terms of labor supply but more in terms of schooling. But, overall, there is no strong difference between individuals who were in their 20s at the beginning of the relationship and those who were older. Although not shown, we also demonstrate that most of the impact appears to influence couples who have been in a relationship for the longest period before the legal change, except in the case of education where it is most visible for more recently united couples.

So far, we assumed that women are the lower earning spouses and thus would be the ones benefitting from alimony payments. However, there are couples for whom this was not the case. While we have no information on the relative income of partners, we can use a crude proxy given by their age difference. Those results are presented in the bottom panel of Table 6. The results are strongly in agreement with the hypothesis that the older spouse would be the one responsible for making alimony payments. The results we have found earlier appear to be concentrated among couples for whom the women was at least 5 years younger, thus making them more likely to obtain alimony in case of separation. ${ }^{25}$ On

\footnotetext{
${ }^{25}$ This group represents about 25 percent of all relationships.
} 
the other hand, results are of the opposite sign (although rarely significant except for the probability of studying) when women were much older than their partners, which is again consistent with the hypothesis that the older partner was more likely to be the one making the alimony payments.

Although the model clearly justifies the results obtained in Table 4, it also suggests that women who enter cohabitation after the legal changes would need to compensate their partners for the obtention of these new rights, in particular during the earlier part of a relationship. This is explored in Table 7 where the sample is the same as that in Panel $\mathrm{B}$ of Table 4: that is, all year-couple observations of a relationship (including at least 10 years following the beginning of a relationship if the relationship does not last long) but where relationships that were "caught" by the change in law are truncated at that point. The first panel simply compares the labor force participation of women and men contrasting relationships formed before and after the legal change. While the statistical significance of the results are limited, the pattern suggested is clearly in harmony with our model: women who enter common-law relationships after the legal change are more likely to work and less likely to study or have work interruptions. The difference in the probability of having a work interruption is of about 7 percent. Panel B explores this pattern more carefully by interacting whether the relationship started before or after the passing of the law with a linear indicator for the number of years since the relationship began. As years go by, women in the new regime should be able to benefit from alimony payments, either because the relationship ends at some point or because it stays active and she receives the payoff she was anticipating within the relationship, which is higher under the new law due to its effect on the intertemporal path of allocations (as in Corollary 2). This is exactly what the results in the bottom panel indicate. We now see that, at the beginning of a relationship, men were more likely to study and less likely to work after the new rules were implemented. Women were less likely to suffer work interruptions. However, with the passage of time, the pattern is reversed as men's labor force participation changes little and that of women decreases. The results are particularly marked for work interruptions where the probability of experiencing a work interruption would eventually favor women 11 years after the beginning of the relationship.

\subsection{Alimony Rights and Relationship Stability}

We have shown in our theoretical section that, when utility is transferable, the 'Becker-Coase' theorem applies resulting in no change in divorce likelihoods following changes in alimony laws. However, this might not be the case when utility is not fully transferable. Hence, we investigate here whether granting alimony rights to relationships change the duration and 
the stability of those relationships. This closely relates to the debate surrounding the impact of no-fault divorce laws on the incidence of divorce in the United States (see, for example, Wolfers, 2006). The threat of separation may be sufficient to alter the way the bargaining power is at play within the relationship but this threat may need to be exercised in some cases when there are frictions in making compensating spousal transfers within the union.

We consider four related outcomes here. First, many cohabitation relationships eventually lead to a formal marriage. However, if cohabitation starts to resemble more traditional legal unions in the eyes of the law, there are less incentives for such a transformation. One may thus expect that granting alimony rights to cohabiting couples may lead fewer of them to "tie the knot". Granting alimony rights also changes the "outside option" of each partner, making it more costly for one and less costly for the other. The overall impact of these rules on the stability of the union is, thus, unclear. We use whether the relationship was still alive at the time of the survey and the length of the cohabitation as our measures of stability. Since there is a potential trade-off with marriage, the total length of the relationship (including any subsequent marriage when relevant) is also included as an outcome.

Table 8 presents the results for these measures. The top panel includes the results for unions formed before the laws were enacted, while Panel B presents those for unions except those that immediately became subject to the new laws once the laws were adopted and Panel $\mathrm{C}$ presents the results of a simple difference-in-difference among unions formed after the legal change. The even columns represent the results when males and females are pooled, and the odd columns, one where all control variables as well as the treatment variable are interacted with a dummy for the respondent being male. The results suggest that the Becker-Coase theorem cannot be rejected in this sample: the likelihood of a couple being separated at the time of the survey in 2002 does not seem to be significantly related to the fact that the union became subject to alimony rights, at least in the case of existing couples. Similarly, being granted alimony rights does not appear to have changed the overall duration of relationships for couples formed before the legal change. However, it does appear to have significantly increased the duration of the cohabitation phase of the relationship by about 2 years and reduced the likelihood of transforming them into marriage by about 14 percent. There is little indication that these impacts differed between male and female respondents. On the other hand, for unions that formed after the laws were changed, being eligible for alimony payments appears to have shortened the duration of cohabitation (and maybe even of the overall duration of the relationship, depending on the estimation strategy used). For none of the outcomes is the impact of being granted alimony rights among all relationships similar in size to the estimated impact in Panel A. 
We then evaluated how robust these results are to some variations. ${ }^{26}$ Six different tests were performed mirroring those of Table 5. First, only rules regarding whether the relationship lasted the required number of years were used, ignoring the exceptions linked to the presence of children. The results were similar in magnitude in significance to the ones presented in Table 8. We then added a number of covariates including the mother tongue, religious background and educational attainment of the respondent. The results, once more, were unaltered by this modification. Next, we explored whether restricting the sample to relationships formed early or late influenced the estimates. When focusing on relationships that began before 1990, we found that granting alimony rights not only lengthened the cohabitation but increased its stability, making it less likely to be over by 2001 and increasing its overall duration by about 1.7 years - a little less than half of the increase in cohabitation length. On the other hand, relationships formed after 1980 displayed a similar pattern as the one highlighted for the entire sample. This could be simply due to the fact that recent relationships were more likely to be censored and, thus, less likely to significantly demonstrate an impact on long-lasting measures such as relationship stability. We repeated the estimation this time excluding all relationships from Quebec. In this sample, the BeckerCoase theorem appeared to be violated again, as relationships that became subject to the alimony rights were 13 percent less likely to have ceased to exist at the time of the survey and would have lasted about 2.6 more years in total. Cohabitation length increased more significantly in this sample but the likelihood of it evolving into a marriage was not changed. Finally, we also introduced a lagged indicator which was equal to one if the couple was to become subject to alimony rules in 2 years. Comfortingly, the coefficient of that dummy variable was small and insignificant (except in the case of overall duration), suggesting that the results presented in the previous table were not simply capturing a time trend. Finally, we also used log duration as an outcome variable because of the likely problem of censoring in that variable and the results remained identical to the ones presented above.

As a final exercise, we explored whether these laws differentially affected individuals with distinct attributes. We found that the likelihood that a relationship was inactive by 2001 appears to have been influenced by the alimony rights more strongly for individuals with less education, those who started the relationship at an older age and those for whom the woman was much older than her partner. ${ }^{27}$ In no subgroup was the total duration of the relationship significantly impacted by the legal change. However, the two variables that were significantly modified by the granting of alimony rights for the entire sample, the likelihood of eventual marriage and the duration of the cohabitation, did appear to respond more strongly in those

\footnotetext{
${ }^{26}$ All estimates discussed but not shown are available upon request.

${ }^{27}$ Several studies have found that early marriages and of uneducated partners tend to be less stable. See, for instance, Weiss and Willis (1997).
} 
groups where the labor supply responses were more visible - that is, individuals with more education, older couples and those where the man was much older than his partner.

\section{Conclusions}

We advanced in this paper a collective intra-household allocation model that incorporates both the process of spousal matching and the prospect of divorce. Doing so, we found elements of policy neutrality, as we identified that changes in alimony laws would affect existing couples and couples-to-be differently.

We then provided some empirical evidence from Canada, using differential rules in distinct Canadian provinces and the fact that those were phased out at different moments over the last 35 years. We found that being offered alimony rights led females to increase their likelihood of attending school and experiencing work interruptions and decreasing their likelihood of working full-time. Males, on the other hand, experienced the opposite pattern once they became subject to the new legislation. All the more important, we also identified contrasting outcomes for the new alimony rights' impact on the behavior of cohabiting couples who got together after the alimony rights were granted: among such couples, men - and not women

- were more likely to study, have more work interruptions, whereas they were less likely to work or work full time.

In a context where, all around the world, many couples choose to cohabitate before or in lieu of marriage, the issues we have explored here appear to be more and more relevant. Our results suggest that while government intervention in this "market" may have short-run impact on existing couples, they are unlikely to be able to alter outcomes more than a simple inter-temporal shift.

Furthermore, our results may also explain the limited number of cohabitation arrangements signed, even when they are legal and likely to be enforced, mirroring the limited number of pre-nuptial agreements (see Weiss and Willis (1993)). The theoretical framework presented highlights that they may only be able to influence the inter-temporal allocation resources, while the expected utility is driven by market forces.

Finally, while our results indicate that more couples subject to these rules were likely to remain in a cohabitation union and not transform it into a marriage, our theoretical framework does not model the choice of marriage versus cohabitation. This is left to future work. 


\section{References}

[1] Amador, D. and R. Bernal. (2008). "The Marriage Gap and the Well-being of Households and Children," Unpublished mimeo, available at http://www.webmeets.com/files/papers/LACEALAMES/2009/367/MarriageGap_version2.pdf.

[2] Ambrus, A., E. Field, and M. Torero. (2010). "Muslim Family Law, Prenuptial Agreements and the Emergence of Dowry in Bangladesh," Quarterly Journal of Economics,, Vol. 125 (3), 1349-1397.

[3] Angrist, J. (2002). "How Do Sex Ratios Affect Marriage and Labor Markets? Evidence from America's Second Generation," The Quarterly Journal of Economics, Vol. 117 (3), 997-1038.

[4] Attanasio, O. and V. Lech̀ene (2009), "Efficient Responses to Targeted Transfers", working paper, UCL.

[5] Barro, R. J. (1974), "Are Government Bonds Net Wealth?," Journal of Political Economy, Vol. 82, 1095-1117.

[6] Becker, G. S. (1973). "A Theory of Marriage: Part i," Journal of Political Economy, Vol. 81 (4), 813-46.

[7] Bergstrom, T. (1989). "A Fresh Look at the Rotten Kid Theorem-and Other Household Mysteries", The Journal of Political Economy, Vol. 97 (5), pp. 1138-1159.

[8] Browning, M., F. Bourguignon, P. A. Chiappori, and V. Lechene. (1994). "Income and Outcomes: A Structural Model of Intrahousehold Allocation," Journal of Political Economy, Vol. 102 (6), 1067-96.

[9] Browning, M., P. A. Chiappori, and Y. Weiss. (2003). "A Simple Matching Model of the Marriage Market," University of Chicago, unpublished manuscript.

[10] Browning, M., P. A. Chiappori, and Y. Weiss. (in progress). Family Economics, (Cambridge: Cambridge University Press).

[11] Chiappori, P. A. (1988). "Rational Household Labor Supply," Econometrica, Vol. 56, 63-90.

[12] Chiappori, P. A. (1992). "Collective Labor Supply and Welfare," Journal of Political Economy, Vol.100 (3), 437-67.

[13] Chiappori, P.-A., B. Fortin, and G. Lacroix. (2002). "Marriage Market, Divorce Legislation, and Household Labor Supply," The Journal of Political Economy, Vol. 110 (1), 37-72.

[14] Chiappori, P. A. M. Iyigun and Y. Weiss. (2007). "Public Goods, Transferable Utility and Divorce Laws," IZA Working Paper No: 2646, March.

[15] Chiappori, P. A. M. Iyigun and Y. Weiss. (2008). "An Assignment Model of Divorce and Remarriage," IZA Working Paper No: 3892, December.

[16] Chiappori, P. A. M. Iyigun and Y. Weiss. (2009). "Investment in Schooling and the Marriage Market," American Economic Review, Vol. 99 (5), 1689-1713. 
[17] Clark, S. (1999), "Law, Property, and Marital Dissolution," The Economic Journal, Vol. 109, c41-c54.

[18] Duflo (2000), "Grandmothers and Granddaughters: Old Age Pension and Intrahousehold Allocation in South Africa", World Bank Economic Review, vol. 17, no. 1, 2003, pp. 1-25

[19] Friedberg, L. (1998). "Did Unilateral Divorce Raise Divorce Rates? Evidence from Panel Data," American Economic Review, Vol. 88 (3), 608-627.

[20] Kocherlakota, N. and L. Pistaferri (2008). "Household Heterogeneity and Asset Trade: Resolving the Equity Premium Puzzle in Three Countries" Unpublished Manuscript, University of Minnesota.

[21] Lafortune, J. (2010). "Making Yourself Attractive: Pre-marital Investments and the Returns to Education in the Marriage Market," Unpublished mimeo available at http://sites.google.com/site/jeannelafortune/papers/Draft-01-2010.pdf

[22] Lazear, E. (2000). "Job Security and Employment," The Quarterly Journal of Economics, Vol. 105, 699-726.

[23] Ligon, E., Thomas, J. and T. Worrall (2002). "Informal Insurance Arrangements with Iimited Commitment: Theory and Evidence from Village Economies," Review of Economic Studies, Vol. 69, 209-244.

[24] Lundberg, S. and R. A. Pollak. (1993). "Separate Spheres Bargaining and the Marriage Market," Journal of Political Economy, Vol. 101 (6), 988-1010.

[25] Manning, W. D. (1995). "Cohabitation, Marriage and Entry into Motherhood," Journal of Marriage and the Family, Vol. 57 (1), 191-200.

[26] Manning, W. D. (2001). "Childbearning in Cohabiting Unions: Racial and Ethnic Differences," Family Planning Perspectives, Vol. 33 (5), 217-223.

[27] Mazzocco, M. (2007). "Household Intertemporal Behaviour: A Collective Characterization and a Test of Commitment," Review of Economic Studies, Vol. 74, 857-895.

[28] Mazzocco, M. and S. Yamaguchi. (2007). "Labor Supply, Wealth Dynamics, and Marriage Decisions," mimeo, Duke University.

[29] Oreffice, S. (2007), 'Did the Legalization of Abortion Increase Women's Household Bargaining Power? Evidence from Labor Supply', Review of Economics of the Household, 5-2, pp. 181-207.

[30] Peters, E. H. (1986). "Marriage and Divorce: Informational Constraints and Private Contracting," American Economic Review, Vol. 76 (3), 437-454.

[31] Rangel, M. A. (2006). "Alimony Rights and Intrahousehold Allocation of Resources: Evidence from Brazil," Economic Journal, Vol. 116 (513), 627-658.

[32] Schoen, R. (1992). "First Unions and the Stability of First Marriages," Journal of Marriage and Family, Vol. 54 (2), 281-284.

[33] Smock, P. (2000). "Cohabitation in the United States: An Appraisal of Research Themes, Findings, and Implications," Annual Reviews Sociology, Vol. 26, 1-20. 
[34] Stevenson, B. (2008). "Divorce Law and Women's Labor Supply," Journal of Empirical Legal Studies, Vol. 5 (4), 853-873.

[35] Weiss, Y. and R. J. Willis (1993). "Transfers among Divorced Couples: Evidence and Interpretation," Journal of Labor Economics, Vol. 11 (4), 629-79.

[36] Weiss, Y. and R. J. Willis (1997). "Match Quality, New Information, and Marital Dissolution," Journal of Labor Economics, Vol. 15 (1) Part 2, , s252-s293.

[37] White, J. M. (1987). "Premarital Cohabitation and Marital Stability in Canada," Journal of Marriage and Family, Vol. 49 (3), 641-647.

[38] Wolfers, J. (2006). "Did Unilateral Divorce Laws Raise Divorce Rates? A Reconciliation and New Results," American Economic Review, Vol. 96 (5), 1802-1820.

\section{Tables and figures}

Table 1: Summary of legislations granting alimony rights to cohabiting couples

\begin{tabular}{lcccc}
\hline Province & Legislation & Year & Length required & Special cases \\
\hline Newfoundland & Family Law Act & 2000 & 2 years & 1 yr with child \\
PEI & Family Law Act & 1995 & 3 years & 1 yr with child \\
Nova Scotia & Maintenance and Custody Act & 1989 & 1 year & \\
New Brunswick & Family Services Act & 1980 & 3 years & \\
Quebec & No law & & & \\
Ontario & Family Law Act & 1978 & 3 years & Auto. with child \\
Manitoba & Family Maintenance Act & 1983 & 5 years & 1 yr with child \\
Saskatchewan & Family Maintenance Act & 1990 & 3 years & Auto. with child \\
Alberta & Domestic Relations Act & 1999 & 3 years & 1 yr with child \\
British Columbia & Family Relations Act & 1979 & 2 years & \\
\hline
\end{tabular}


Table 2: Summary statistics (cross-section sample)

\begin{tabular}{|c|c|c|c|c|c|c|c|c|c|}
\hline & \multicolumn{6}{|c|}{ Cohabitations } & \multirow{2}{*}{\multicolumn{3}{|c|}{$\begin{array}{c}\text { Marriages } \\
\text { all }\end{array}$}} \\
\hline & \multicolumn{3}{|c|}{ before the law } & \multicolumn{3}{|c|}{ after the law } & & & \\
\hline & $\mathrm{N}$ & mean & st.d. & $\mathrm{N}$ & mean & st.d. & $\mathrm{N}$ & $\begin{array}{l}\text { all } \\
\text { mean }\end{array}$ & st.d. \\
\hline \multicolumn{10}{|l|}{ Demographic characteristics } \\
\hline Age relationship began & 4025 & 25.98 & 8.46 & 3495 & 27.17 & 8.72 & 11279 & 26.18 & 7.69 \\
\hline Male & 4025 & 0.47 & 0.50 & 3495 & 0.48 & 0.50 & 11279 & 0.48 & 0.50 \\
\hline English-speaking & 4020 & 0.28 & 0.45 & 3484 & 0.88 & 0.32 & 11235 & 0.68 & 0.47 \\
\hline French-speaking & 4020 & 0.70 & 0.46 & 3484 & 0.07 & 0.25 & 11235 & 0.26 & 0.44 \\
\hline Catholic & 4001 & 0.70 & 0.46 & 3436 & 0.27 & 0.44 & 11077 & 0.44 & 0.50 \\
\hline Atheist & 4001 & 0.13 & 0.34 & 3436 & 0.35 & 0.48 & 11077 & 0.15 & 0.36 \\
\hline Protestant & 4001 & 0.14 & 0.35 & 3436 & 0.35 & 0.48 & 11077 & 0.39 & 0.49 \\
\hline Attended rel. services at age 15 & 3990 & 0.42 & 0.49 & 3432 & 0.36 & 0.48 & 11012 & 0.59 & 0.49 \\
\hline High school graduate & 4024 & 0.81 & 0.39 & 3487 & 0.84 & 0.37 & 11255 & 0.81 & 0.40 \\
\hline College graduate & 4024 & 0.19 & 0.39 & 3487 & 0.17 & 0.38 & 11255 & 0.20 & 0.40 \\
\hline \multicolumn{10}{|l|}{ Relationship characteristics } \\
\hline Ended as marriage & 4025 & 0.34 & 0.47 & 3495 & 0.40 & 0.49 & 11279 & 1.00 & 0.00 \\
\hline Relationship has ended & 4025 & 0.49 & 0.50 & 3495 & 0.39 & 0.49 & 11279 & 0.28 & 0.45 \\
\hline Duration (years) & 4025 & 5.07 & 5.46 & 3495 & 3.45 & 3.62 & 11279 & 16.03 & 11.36 \\
\hline Duration (total in years) & 4025 & 8.90 & 7.90 & 3547 & 6.40 & 5.91 & 11279 & 16.03 & 11.36 \\
\hline \multicolumn{10}{|l|}{ Partner's characteristics } \\
\hline Spouse was prev. unmarried & 4019 & 0.76 & 0.43 & 3495 & 0.71 & 0.45 & 11266 & 0.86 & 0.35 \\
\hline Age difference (own-spouse) & 3573 & -0.61 & 4.87 & 3201 & -0.50 & 4.84 & 11024 & -0.28 & 4.21 \\
\hline Women at least 5 years older & 3573 & 0.06 & 0.24 & 3201 & 0.08 & 0.26 & 11024 & 0.03 & 0.17 \\
\hline Male at least 5 years older & 3573 & 0.24 & 0.43 & 3201 & 0.24 & 0.42 & 11024 & 0.20 & 0.40 \\
\hline \multicolumn{10}{|l|}{ Legislative status } \\
\hline Subject to alimony rights & 3967 & 0.06 & 0.23 & 3495 & 0.74 & 0.44 & 11279 & 0.61 & 0.49 \\
\hline with no child rules & 3967 & 0.06 & 0.23 & 3495 & 0.53 & 0.50 & 11279 & 0.60 & 0.49 \\
\hline
\end{tabular}

All statistics weighted by person-specific weights. 
Table 3: Summary statistics (panel sample)

\begin{tabular}{lccccccc}
\hline & \multicolumn{3}{c}{ Cohabitations } & \multicolumn{3}{c}{$\begin{array}{c}\text { Marriages } \\
\text { all }\end{array}$} \\
& $\begin{array}{l}\text { Mefore the law } \\
\text { Mean }\end{array}$ & St. Dev. & Mean & St. Dev. & Mean & St. Dev \\
\hline Including all active relationships & \multicolumn{2}{c}{$\mathrm{N}=24286$} & \multicolumn{2}{c}{$\mathrm{N}=15513$} & $\mathrm{~N}=186304$ \\
Subject to alimony rights & 0.05 & 0.21 & 0.49 & 0.50 & 0.42 & 0.49 \\
Subject to alimony rights-no child rules & 0.04 & 0.21 & 0.44 & 0.50 & 0.40 & 0.49 \\
Studied & 0.11 & 0.31 & 0.13 & 0.33 & 0.07 & 0.25 \\
Worked & 0.75 & 0.43 & 0.74 & 0.44 & 0.75 & 0.43 \\
Worked full time & 0.66 & 0.47 & 0.62 & 0.49 & 0.64 & 0.48 \\
Stopped working & 0.11 & 0.32 & 0.10 & 0.30 & 0.16 & 0.37 \\
Number of children & 0.87 & 1.15 & 0.86 & 1.16 & 1.68 & 1.27 \\
Had a maternity leave & 0.04 & 0.20 & 0.03 & 0.17 & 0.07 & 0.25 \\
Had a paternity leave & 0.00 & 0.05 & 0.00 & 0.04 & 0.00 & 0.03 \\
& & & & & & \\
Including at least 10 years & $\mathrm{N}=39066$ & $\mathrm{~N}=26379$ & $\mathrm{~N}=194427$ \\
Subject to alimony rights & 0.04 & 0.18 & 0.34 & 0.47 & 0.40 & 0.49 \\
Subject to alimony rights-no child rules & 0.04 & 0.17 & 0.26 & 0.44 & 0.38 & 0.49 \\
Studied & 0.11 & 0.32 & 0.12 & 0.32 & 0.07 & 0.25 \\
Worked & 0.76 & 0.43 & 0.74 & 0.44 & 0.75 & 0.43 \\
Worked full time & 0.66 & 0.47 & 0.62 & 0.48 & 0.64 & 0.48 \\
Stopped working & 0.13 & 0.34 & 0.12 & 0.33 & 0.16 & 0.37 \\
Number of children & 0.90 & 1.12 & 0.93 & 1.14 & 1.66 & 1.27 \\
Had a maternity leave & 0.06 & 0.23 & 0.05 & 0.21 & 0.07 & 0.25 \\
Had a paternity leave & 0.00 & 0.06 & 0.00 & 0.04 & 0.00 & 0.03 \\
\hline
\end{tabular}

All statistics weighted by person-specific weights. 
Table 4: Impact of alimony rights on labor supply

\begin{tabular}{|c|c|c|c|c|c|c|}
\hline & $\begin{array}{l}\text { Studied } \\
\text { (1) }\end{array}$ & $\begin{array}{c}\text { Worked } \\
\text { (2) }\end{array}$ & $\begin{array}{l}\text { Worked } \\
\text { full time } \\
\qquad(3)\end{array}$ & $\begin{array}{c}\text { Work } \\
\text { interruptions } \\
(4) \\
\end{array}$ & $\begin{array}{l}\text { Maternity } \\
\text { leave } \\
(5)\end{array}$ & $\begin{array}{c}\text { Paternity } \\
\text { leave } \\
(6)\end{array}$ \\
\hline & \multicolumn{6}{|c|}{ Panel A: Only relationships formed before a law was passed } \\
\hline Subject to alimony rights & $\begin{array}{l}0.020 \dagger \\
(0.011)\end{array}$ & $\begin{array}{l}-0.030 \\
(0.022)\end{array}$ & $\begin{array}{r}-0.047 \dagger \\
(0.024)\end{array}$ & $\begin{array}{l}0.053 \dagger \\
(0.027)\end{array}$ & $\begin{array}{c}0.024 \\
(0.019)\end{array}$ & \\
\hline $\begin{array}{l}\text { Subject to alimony rights } \\
\text { male }\end{array}$ & $\begin{array}{r}-0.040 \dagger \\
(0.018)\end{array}$ & $\begin{array}{l}0.086^{*} \\
(0.035)\end{array}$ & $\begin{array}{l}0.104^{*} \\
(0.034)\end{array}$ & $\begin{array}{r}-0.070 \dagger \\
(0.036)\end{array}$ & & $\begin{array}{l}-0.002 \\
(0.003)\end{array}$ \\
\hline $\mathrm{R}$-square & 0.475 & 0.701 & 0.722 & 0.445 & 0.375 & 0.101 \\
\hline \multirow[t]{2}{*}{ N } & 39066 & 39066 & 39066 & 39066 & 22242 & 16824 \\
\hline & \multicolumn{6}{|c|}{ Panel B: All relationships except those "caught" } \\
\hline Subject to alimony rights & $\begin{array}{c}0.009 \\
(0.013)\end{array}$ & $\begin{array}{c}0.030 \\
(0.021)\end{array}$ & $\begin{array}{l}0.058 \dagger \\
(0.030)\end{array}$ & $\begin{array}{l}-0.059^{*} \\
(0.025)\end{array}$ & $\begin{array}{c}-0.054 \dagger \\
(0.026)\end{array}$ & \\
\hline $\begin{array}{l}\text { Subject to alimony rights } \\
\text { male }\end{array}$ & $\begin{array}{c}0.019 \\
(0.035)\end{array}$ & $\begin{array}{l}-0.002 \\
(0.023)\end{array}$ & $\begin{array}{l}-0.018 \\
(0.024)\end{array}$ & $\begin{array}{c}0.038 \\
(0.033)\end{array}$ & & $\begin{array}{l}-0.004 \\
(0.003)\end{array}$ \\
\hline R-square & 0.485 & 0.716 & 0.731 & 0.445 & 0.375 & 0.094 \\
\hline \multirow[t]{2}{*}{$\mathrm{N}$} & 63305 & 63305 & 63305 & 63305 & 35957 & 27348 \\
\hline & \multicolumn{6}{|c|}{ Panel C: Only relationships formed after the legal change } \\
\hline Subject to alimony rights & $\begin{array}{l}-0.003 \\
(0.010)\end{array}$ & $\begin{array}{c}0.008 \\
(0.020)\end{array}$ & $\begin{array}{l}0.032 \dagger \\
(0.017)\end{array}$ & $\begin{array}{l}-0.010 \\
(0.010)\end{array}$ & $\begin{array}{l}-0.002 \\
(0.017)\end{array}$ & \\
\hline $\begin{array}{l}\text { Subject to alimony rights } \\
\text { male }\end{array}$ & $\begin{array}{c}0.015 \\
(0.022)\end{array}$ & $\begin{array}{c}0.030 \\
(0.021)\end{array}$ & $\begin{array}{l}0.011 \\
(0.014)\end{array}$ & $\begin{array}{l}-0.017 \\
(0.015)\end{array}$ & & $\begin{array}{l}-0.002 \\
(0.003)\end{array}$ \\
\hline R-square & 0.498 & 0.738 & 0.741 & 0.434 & 0.343 & 0.123 \\
\hline $\mathrm{N}$ & 26379 & 26379 & 26379 & 26379 & 14883 & 11496 \\
\hline \multicolumn{7}{|c|}{ T-test of equality between the coefficients... } \\
\hline Panel A vs. B (main effect) & 0.48 & $4.16 \dagger$ & $8.01^{*}$ & $9.86^{* *}$ & $6.33^{*}$ & 0.17 \\
\hline Panel A vs. B (interaction) & 2.36 & $4.53^{*}$ & $8.88^{* *}$ & $5.27^{*}$ & & \\
\hline Panel A vs. C (main effect) & 2.71 & 1.78 & $7.67^{*}$ & $5.24 *$ & 1.10 & 0.06 \\
\hline Panel A vs. C (interaction) & $4.05 \dagger$ & 1.94 & $6.61^{*}$ & 1.99 & & \\
\hline
\end{tabular}

Equation (24) specifies the estimation equation for Panel B. Panel A excludes estimates of $\delta_{k}$ and Panel C includes only estimates of $\gamma_{k}, \rho_{k}, \mu_{j}$ and $\nu_{i}$ from that equation. All regressions are weighted using person-specific weights. The sample includes at least ten years following the beginning of any cohabitation relationship or all the years if the relationship lasted longer. In Panel A, only relations formed before the legislation changed are included, in Panel B, all relationships except years in which relationships formed before the law were subject to alimony rights are included. In Panel C, only relationships formed after the legal change are included.

Standard errors are clustered at the province level.

$\dagger: 10 \%$ significance, $*$ : $5 \%$ significance, $* *: 1 \%$ significance 
Table 5: Impact of alimony rules on labor supply-robustness checks

\begin{tabular}{|c|c|c|c|c|c|c|c|}
\hline & $\begin{array}{l}\text { No child } \\
\text { rules } \\
(1)\end{array}$ & $\begin{array}{l}\text { Only } \\
\text { active rel. } \\
\quad(2)\end{array}$ & $\begin{array}{c}\text { Before } \\
1990 \\
(3)\end{array}$ & $\begin{array}{c}\text { After } \\
1980 \\
(4)\end{array}$ & $\begin{array}{l}\text { Without } \\
\text { Quebec } \\
(5)\end{array}$ & $\begin{array}{l}\text { Married } \\
\qquad(6)\end{array}$ & $\begin{array}{l}\text { Lagged } \\
\qquad(7)\end{array}$ \\
\hline & \multicolumn{7}{|c|}{ Panel A: Studied } \\
\hline Subject to alimony rights & $\begin{array}{c}0.020 \dagger \\
(0.011)\end{array}$ & $\begin{array}{c}0.022 \\
(0.013)\end{array}$ & $\begin{array}{c}0.008 \\
(0.014)\end{array}$ & $\begin{array}{l}0.038^{*} \\
(0.012)\end{array}$ & $\begin{array}{c}0.013 \\
(0.012)\end{array}$ & $\begin{array}{c}0.002 \\
(0.004)\end{array}$ & $\begin{array}{c}0.030 \dagger \\
(0.016)\end{array}$ \\
\hline $\begin{array}{l}\text { Subject to alimony rights } \\
\text { male }\end{array}$ & $\begin{array}{l}-0.038 \dagger \\
(0.017)\end{array}$ & $\begin{array}{l}-0.034 \\
(0.020)\end{array}$ & $\begin{array}{l}-0.027 \\
(0.021)\end{array}$ & $\begin{array}{c}-0.075^{* *} \\
(0.016)\end{array}$ & $\begin{array}{l}-0.034 \\
(0.030)\end{array}$ & $\begin{array}{l}-0.003 \\
(0.005)\end{array}$ & $\begin{array}{r}-0.067^{*} \\
(0.023)\end{array}$ \\
\hline $\begin{array}{l}\text { Will be subject to } \\
\text { alimony in } 2 \text { years }\end{array}$ & & & & & & & $\begin{array}{l}-0.008 \\
(0.033)\end{array}$ \\
\hline $\begin{array}{l}\text { Will be subject to } \\
\text { alimony in } 2 \text { years*male }\end{array}$ & & & & & & & $\begin{array}{c}0.066 \\
(0.040)\end{array}$ \\
\hline R-square & 0.475 & 0.574 & 0.450 & 0.477 & 0.373 & 0.429 & 0.476 \\
\hline \multirow[t]{2}{*}{$\mathrm{N}$} & 38793 & 24286 & 29212 & 27795 & 14848 & 150347 & 39066 \\
\hline & \multicolumn{7}{|c|}{ Panel B: Worked full time } \\
\hline Subject to alimony rights & $\begin{array}{r}-0.044 \dagger \\
(0.021)\end{array}$ & $\begin{array}{l}-0.028 \\
(0.022)\end{array}$ & $\begin{array}{l}-0.062 \dagger \\
(0.030)\end{array}$ & $\begin{array}{l}-0.031 \\
(0.027)\end{array}$ & $\begin{array}{c}-0.125^{* *} \\
(0.031)\end{array}$ & $\begin{array}{c}0.008 \\
(0.007)\end{array}$ & $\begin{array}{r}-0.072^{* *} \\
(0.018)\end{array}$ \\
\hline $\begin{array}{l}\text { Subject to alimony rights } \\
\text { male }\end{array}$ & $\begin{array}{l}0.097^{*} \\
(0.030)\end{array}$ & $\begin{array}{c}0.076 \dagger \\
(0.037)\end{array}$ & $\begin{array}{l}0.127^{* *} \\
(0.035)\end{array}$ & $\begin{array}{l}0.108^{*} \\
(0.041)\end{array}$ & $\begin{array}{c}0.229 * * \\
(0.065)\end{array}$ & $\begin{array}{l}-0.006 \\
(0.007)\end{array}$ & $\begin{array}{c}0.134^{* *} \\
(0.036)\end{array}$ \\
\hline $\begin{array}{l}\text { Will be subject to } \\
\text { alimony in } 2 \text { years } \\
\text { Will be subject to } \\
\text { alimony in } 2 \text { years*male }\end{array}$ & & & & & & & $\begin{array}{l}0.045 \\
(0.041) \\
-0.079 \\
(0.061)\end{array}$ \\
\hline R-square & 0.720 & 0.775 & 0.717 & 0.727 & 0.703 & 0.723 & 0.723 \\
\hline \multirow[t]{2}{*}{$\mathrm{N}$} & 38793 & 24286 & 29212 & 27795 & 14848 & 150347 & 39066 \\
\hline & \multicolumn{7}{|c|}{ Panel C: Work Interruption } \\
\hline Subject to alimony rights & $\begin{array}{l}0.070^{*} \\
(0.025)\end{array}$ & $\begin{array}{c}0.054 \\
(0.030)\end{array}$ & $\begin{array}{c}0.060 \\
(0.037)\end{array}$ & $\begin{array}{c}0.068 \dagger \\
(0.029)\end{array}$ & $\begin{array}{c}0.021 \\
(0.031)\end{array}$ & $\begin{array}{c}-0.035^{* *} \\
(0.008)\end{array}$ & $\begin{array}{c}0.052 \\
(0.031)\end{array}$ \\
\hline $\begin{array}{l}\text { Subject to alimony rights } \\
\text { male }\end{array}$ & $\begin{array}{r}-0.080^{*} \\
(0.032)\end{array}$ & $\begin{array}{l}-0.051 \\
(0.044)\end{array}$ & $\begin{array}{l}-0.082 \\
(0.048)\end{array}$ & $\begin{array}{r}-0.097^{*} \\
(0.033)\end{array}$ & $\begin{array}{l}-0.054 \\
(0.042)\end{array}$ & $\begin{array}{c}0.054^{* *} \\
(0.014)\end{array}$ & $\begin{array}{l}-0.070 \\
(0.039)\end{array}$ \\
\hline $\begin{array}{l}\text { Will be subject to } \\
\text { alimony in } 2 \text { years }\end{array}$ & & & & & & & $\begin{array}{l}-0.054 \\
(0.044)\end{array}$ \\
\hline $\begin{array}{l}\text { Will be subject to } \\
\text { alimony in } 2 \text { years*male }\end{array}$ & & & & & & & $\begin{array}{c}0.077 \\
(0.046)\end{array}$ \\
\hline R-square & 0.435 & 0.471 & 0.423 & 0.443 & 0.439 & 0.523 & 0.446 \\
\hline $\mathrm{N}$ & 38793 & 24286 & 29212 & 27795 & 14848 & 150347 & 39066 \\
\hline
\end{tabular}

All regressions include the same controls as in Panel B of the previous table. All regressions are weighted using person-specific weights. The sample includes at least ten years following the beginning of any cohabitation relationship, except in column (2) where it includes only years where the cohabitation relationship was active. The first column only includes, as subject to alimony rules, couples who qualified because of the duration of their relationship, not because they had children. The third restricts it to relationships that began before 1990, the next one, to couples formed before 1980. The fifth column excludes all couples from Quebec. The sixth only includes married couples and the last includes an injdicator for becoming subject to the law in 2 years.

Standard errors are clustered at the province level. $\dagger: 10 \%$ significance, ${ }^{*}: 5 \%$ significance, ${ }^{* *}: 1 \%$ significance 
Table 6: Impact of alimony rights on labor supply-heterogenous effects

\begin{tabular}{|c|c|c|c|c|c|c|}
\hline & \multicolumn{2}{|c|}{ Studied } & \multicolumn{2}{|c|}{ Worked full time } & \multicolumn{2}{|c|}{ Work Interruptions } \\
\hline & $\begin{array}{c}\text { Main effect } \\
\text { (1) }\end{array}$ & $\begin{array}{c}\text { Interaction } \\
(2)\end{array}$ & $\begin{array}{c}\text { Main effect } \\
(3)\end{array}$ & $\begin{array}{l}\text { Interaction } \\
(4)\end{array}$ & $\begin{array}{c}\text { Main effect } \\
(5)\end{array}$ & $\begin{array}{c}\text { Interaction } \\
(6)\end{array}$ \\
\hline \multicolumn{7}{|l|}{ By education: } \\
\hline$\overline{\text { Less than high school }}$ & $\begin{array}{c}0.021 \\
(0.022)\end{array}$ & $\begin{array}{c}0.000 \\
(0.031)\end{array}$ & $\begin{array}{c}0.029 \\
(0.036)\end{array}$ & $\begin{array}{c}0.014 \\
(0.037)\end{array}$ & $\begin{array}{c}0.096 \dagger \\
(0.044)\end{array}$ & $\begin{array}{l}-0.109 \\
(0.062)\end{array}$ \\
\hline High school graduate & $\begin{array}{c}0.027^{*} \\
(0.010)\end{array}$ & $\begin{array}{l}-0.046 \\
(0.030)\end{array}$ & $\begin{array}{l}-0.053 \\
(0.044)\end{array}$ & $\begin{array}{c}0.107 \dagger \\
(0.054)\end{array}$ & $\begin{array}{c}0.040 \\
(0.039)\end{array}$ & $\begin{array}{l}-0.045 \\
(0.051)\end{array}$ \\
\hline College graduate & $\begin{array}{l}-0.019 \\
(0.048)\end{array}$ & $\begin{array}{l}-0.210 \\
(0.127)\end{array}$ & $\begin{array}{c}-0.184^{*} \\
(0.073)\end{array}$ & $\begin{array}{c}0.335^{* *} \\
(0.091)\end{array}$ & $\begin{array}{c}0.032 \\
(0.078)\end{array}$ & $\begin{array}{l}-0.147 \\
(0.136)\end{array}$ \\
\hline \multicolumn{7}{|l|}{ By age: } \\
\hline Began rel. before age 21 & $\begin{array}{c}0.063 \dagger \\
(0.033)\end{array}$ & $\begin{array}{l}-0.025 \\
(0.057)\end{array}$ & $\begin{array}{c}0.034 \\
(0.054)\end{array}$ & $\begin{array}{c}0.043 \\
(0.118)\end{array}$ & $\begin{array}{c}-0.002 \\
(0.060)\end{array}$ & $\begin{array}{c}0.021 \\
(0.052)\end{array}$ \\
\hline Began rel. between $22-27$ & $\begin{array}{l}-0.005 \\
(0.017)\end{array}$ & $\begin{array}{c}-0.017 \\
(0.026)\end{array}$ & $\begin{array}{c}-0.086 \\
(0.047)\end{array}$ & $\begin{array}{l}0.142^{*} \\
(0.047)\end{array}$ & $\begin{array}{c}0.085 \\
(0.064)\end{array}$ & $\begin{array}{l}-0.111 \\
(0.069)\end{array}$ \\
\hline Began rel. after 28 & $\begin{array}{c}0.008 \\
(0.044)\end{array}$ & $\begin{array}{c}-0.081 \\
(0.061)\end{array}$ & $\begin{array}{c}-0.079 \dagger \\
(0.037)\end{array}$ & $\begin{array}{c}0.117 \\
(0.067)\end{array}$ & $\begin{array}{c}0.069 \\
(0.073)\end{array}$ & $\begin{array}{l}-0.100 \\
(0.078)\end{array}$ \\
\hline \multicolumn{7}{|l|}{ By age difference: } \\
\hline$\overline{\text { Fem. at least } 5 \text { yrs younger }}$ & $\begin{array}{c}0.063 \\
(0.035)\end{array}$ & $\begin{array}{c}-0.109^{* *} \\
(0.017)\end{array}$ & $\begin{array}{c}-0.090^{*} \\
(0.035)\end{array}$ & $\begin{array}{c}0.187^{* *} \\
(0.049)\end{array}$ & $\begin{array}{c}0.158^{*} \\
(0.054)\end{array}$ & $\begin{array}{c}-0.211^{*} \\
(0.075)\end{array}$ \\
\hline Within 5 years of spouse & $\begin{array}{l}-0.012 \\
(0.024)\end{array}$ & $\begin{array}{l}-0.010 \\
(0.036)\end{array}$ & $\begin{array}{l}-0.024 \\
(0.025)\end{array}$ & $\begin{array}{c}0.031 \\
(0.032)\end{array}$ & $\begin{array}{c}0.016 \\
(0.055)\end{array}$ & $\begin{array}{l}-0.005 \\
(0.069)\end{array}$ \\
\hline Fem. at least 5 yrs older & $\begin{array}{l}-0.003 \\
(0.013)\end{array}$ & $\begin{array}{l}0.062^{*} \\
(0.025)\end{array}$ & $\begin{array}{c}0.043 \\
(0.034)\end{array}$ & $\begin{array}{l}-0.107 \\
(0.060)\end{array}$ & $\begin{array}{l}-0.032 \\
(0.056)\end{array}$ & $\begin{array}{l}-0.030 \\
(0.057)\end{array}$ \\
\hline
\end{tabular}

All regressions include the same controls as in Panel B of Table 4. All regressions are weighted using person-specific weights. The sample includes at least ten years following the beginning of any cohabitation relationship. Each set of columns and section of the table correspond to a regression. The table entries are the coefficients of an indicator for the couple being subject to alimony rules interacted with the characteristics as listed in the first column of the table (for columns (1), (3), (5)) and the interaction of that term with a dummy for the respondent being a male in columns (2), (4) and (6).

Standard errors are clustered at the province level.

$\dagger$ : $10 \%$ significance, $*: 5 \%$ significance, $* *: 1 \%$ significance 
Table 7: Policy neutrality of alimony rights rules

\begin{tabular}{lcccc}
\hline & Studied & Worked & $\begin{array}{c}\text { Worked } \\
\text { Full-Time }\end{array}$ & $\begin{array}{c}\text { Work } \\
\text { Interruption } \\
\text { Panel A: Comparing new and old relationship }(\mathrm{N}=63493)\end{array}$ \\
\hline \multicolumn{1}{c}{ Formed after a legal change } & -0.076 & 0.003 & 0.017 & $-0.076^{* *}$ \\
& $(0.208)$ & $(0.034)$ & $(0.029)$ & $(0.020)$ \\
Formed after a legal change*male & 0.001 & 0.003 & -0.053 & $0.071^{* *}$ \\
& $(0.453)$ & $(0.036)$ & $(0.037)$ & $(0.021)$ \\
R-square & 0.021 & 0.046 & 0.055 & 0.037 \\
Panel B: Comparing new and long relationships & over time $(\mathrm{N}=63493)$ \\
Formed after a legal change & -0.013 & 0.004 & 0.020 & $-0.091^{* *}$ \\
Formed after a legal change*male & $0.033^{* *}$ & -0.005 & $-0.061 \dagger$ & $0.083^{* *}$ \\
Formed after a legal change & $(0.010)$ & $(0.032)$ & $(0.033)$ & $(0.024)$ \\
time since beginning & -0.002 & $-0.004^{*}$ & $-0.005^{* *}$ & $0.008^{* *}$ \\
Formed after a legal change & $(0.001)$ & $(0.001)$ & $(0.002)$ & $(0.001)$ \\
time since beginning*male & 0.000 & 0.004 & $0.006^{*}$ & $-0.007^{* *}$ \\
R-square & $(0.001)$ & $(0.003)$ & $(0.002)$ & $(0.001)$ \\
\hline All & 0.032 & 0.047 & 0.056 & 0.039 \\
\hline
\end{tabular}

All regressions include fixed effects for province, year of observation and their interactions with a male dummy. Regressions in Panel B also include controls for the duration of the relationship and its interaction with being male. The sample includes at least ten years following the beginning of any cohabitation relationship except for years where the couple was subject to alimony rights when they had entered into the relationship before the legal change. All regressions are weighted using person-specific weights.

Standard errors are clustered at the province level.

$\dagger: 10 \%$ significance, ${ }^{*}: 5 \%$ significance, ${ }^{* *}: 1 \%$ significance 
Table 8: Impact of alimony rules on relationship stability

\begin{tabular}{|c|c|c|c|c|c|c|c|c|}
\hline & \multicolumn{2}{|c|}{$\begin{array}{l}\text { Relationship } \\
\text { is over in } 2001\end{array}$} & \multicolumn{2}{|c|}{$\begin{array}{l}\text { Cohabitation led } \\
\text { to marriage }\end{array}$} & \multicolumn{2}{|c|}{ Duration } & \multicolumn{2}{|c|}{$\begin{array}{c}\text { Duration } \\
\text { (total) }\end{array}$} \\
\hline & $(1)$ & $(2)$ & (3) & (4) & (5) & (6) & (7) & (8) \\
\hline & \multicolumn{8}{|c|}{ Panel A: Only relationships formed before a law was passed } \\
\hline Subj. to alimony rights & $\begin{array}{l}-0.109 \\
(0.081)\end{array}$ & $\begin{array}{l}-0.117 \\
(0.085)\end{array}$ & $\begin{array}{c}-0.140^{* *} \\
(0.025)\end{array}$ & $\begin{array}{c}-0.177^{* *} \\
(0.047)\end{array}$ & $\begin{array}{l}2.604^{*} \\
(0.806)\end{array}$ & $\begin{array}{l}2.125^{*} \\
(0.705)\end{array}$ & $\begin{array}{c}0.530 \\
(0.762)\end{array}$ & $\begin{array}{c}0.505 \\
(1.180)\end{array}$ \\
\hline $\begin{array}{l}\text { Subj. to alimony rights } \\
\text { male }\end{array}$ & & $\begin{array}{c}0.063 \\
(0.063)\end{array}$ & & $\begin{array}{c}0.064 \\
(0.098)\end{array}$ & & $\begin{array}{l}0.468 \\
(0.517)\end{array}$ & & $\begin{array}{l}-1.122 \\
(1.643)\end{array}$ \\
\hline R-square & 0.294 & 0.308 & 0.262 & 0.275 & 0.917 & 0.921 & 0.480 & 0.495 \\
\hline $\mathrm{N}$ & 4025 & 4025 & 4025 & 4025 & 4025 & 4025 & 4014 & 4014 \\
\hline \multicolumn{9}{|c|}{ Panel B: All relationships except those "caught" } \\
\hline Subj. to alimony rights & $\begin{array}{c}0.051 \\
(0.038)\end{array}$ & $\begin{array}{c}0.029 \\
(0.035)\end{array}$ & $\begin{array}{l}-0.007 \\
(0.020)\end{array}$ & $\begin{array}{c}0.017 \\
(0.029)\end{array}$ & $\begin{array}{l}-0.211^{*} \\
(0.084)\end{array}$ & $\begin{array}{r}-0.347^{*} \\
(0.114)\end{array}$ & $\begin{array}{l}-1.262 \dagger \\
(0.620)\end{array}$ & $\begin{array}{l}-0.587 \\
(0.692)\end{array}$ \\
\hline $\begin{array}{l}\text { Subj. to alimony rights } \\
\text { male }\end{array}$ & & $\begin{array}{c}0.063 \\
(0.043)\end{array}$ & & $\begin{array}{l}-0.045 \\
(0.060)\end{array}$ & & $\begin{array}{l}0.230 \dagger \\
(0.108)\end{array}$ & & $\begin{array}{l}-1.806 \\
(1.010)\end{array}$ \\
\hline $\mathrm{R}$-square & 0.261 & 0.269 & 0.262 & 0.276 & 0.955 & 0.956 & 0.502 & 0.516 \\
\hline $\mathrm{N}$ & 7163 & 7163 & 7163 & 7163 & 7163 & 7163 & 7147 & 7147 \\
\hline \multicolumn{9}{|c|}{ Panel C: Only relationships formed after the legal change } \\
\hline Subj. to alimony rights & $\begin{array}{l}-0.029 \\
(0.016)\end{array}$ & $\begin{array}{l}-0.059^{*} \\
(0.018)\end{array}$ & $\begin{array}{c}0.007 \\
(0.014)\end{array}$ & $\begin{array}{l}-0.036 \\
(0.025)\end{array}$ & $\begin{array}{l}-0.097 \dagger \\
(0.044)\end{array}$ & $\begin{array}{l}-0.046 \\
(0.091)\end{array}$ & $\begin{array}{l}-0.210 \\
(0.242)\end{array}$ & $\begin{array}{l}-0.149 \\
(0.414)\end{array}$ \\
\hline $\begin{array}{l}\text { Subj. to alimony rights } \\
\text { male }\end{array}$ & & $\begin{array}{l}0.082 \dagger \\
(0.038)\end{array}$ & & $\begin{array}{c}0.092 \dagger \\
(0.044)\end{array}$ & & $\begin{array}{l}-0.108 \\
(0.103)\end{array}$ & & $\begin{array}{l}-0.199 \\
(0.627)\end{array}$ \\
\hline $\mathrm{R}$-square & 0.210 & 0.224 & 0.259 & 0.279 & 0.948 & 0.948 & 0.555 & 0.578 \\
\hline $\mathrm{N}$ & 3495 & 3495 & 3495 & 3495 & 3495 & 3495 & 3489 & 3489 \\
\hline
\end{tabular}

Equation (24) specifies the estimation equation for Panel B. Panel A excludes estimates of $\delta_{k}$ and Panel $\mathrm{C}$ includes only estimates of $\gamma_{k}, \rho_{k}$ and fixed effects for province from that equation. All regressions are weighted using person-specific weights.

Standard errors are clustered at the province level.

$\dagger: 10 \%$ significance, ${ }^{*}: 5 \%$ significance, ${ }^{* *}: 1 \%$ significance 